Article

\title{
A Systematic Approach to Predict the Economic and Environmental Effects of the Cost-Optimal Energy Renovation of a Historic Building District on the District Heating System
}

\author{
Vlatko Milić $^{1, *}$, Shahnaz Amiri ${ }^{1,2}$ and Bahram Moshfegh 1,2 \\ 1 Division of Energy Systems, Department of Management and Engineering, Linköping University, \\ 58183 Linköping, Sweden; shahnaz.amiri@liu.se (S.A.); bahram.moshfegh@liu.se (B.M.) \\ 2 Division of Building, Energy and Environment Technology, Department of Technology and Environment, \\ University of Gävle, 80176 Gävle, Sweden \\ * Correspondence: vlatko.milic@liu.se; Tel.: +46-1328-4751
}

Received: 2 December 2019; Accepted: 3 January 2020; Published: 6 January 2020

\begin{abstract}
The economic and environmental performance of a district heating (DH) system is to a great extent affected by the size and dynamic behavior of the DH load. By implementing energy efficiency measures (EEMs) to increase a building's thermal performance and by performing cost-optimal energy renovation, the operation of the DH system will be altered. This study presents a systematic approach consisting of building categorization, life cycle cost (LCC) optimization, building energy simulation and energy system optimization procedures, investigating the profitability and environmental performance of cost-optimal energy renovation of a historic building district on the DH system. The results show that the proposed approach can successfully be used to predict the economic and environmental effects of cost-optimal energy renovation of a building district on the local DH system. The results revealed that the financial gains of the district are between 186 MSEK (23\%) and 218 MSEK (27\%) and the financial losses for the DH system vary between 117-194 MSEK (5-8\%). However, the suggested renovation measures decrease the local and global $\mathrm{CO}_{2}$ emissions by $71-75$ metric ton of $\mathrm{CO}_{2 \text { eq. }} /$ year (4\%) and 3545-3727 metric ton of $\mathrm{CO}_{2 \text { eq. }} /$ year (41-43\%), respectively. Total primary energy use was decreased from $57.2 \mathrm{GWh} /$ year to $52.0-52.2 \mathrm{GWh} /$ year.
\end{abstract}

Keywords: LCC optimization; building energy simulation; energy system optimization; energy renovation; historic building district; district heating system

\section{Introduction}

Fossil fuel supply sources dominate the European building heat market, representing approximately $66 \%$ of the total end-use heat demand [1]. The total final energy use in the residential and services sector in Sweden in 2017 was 146 TWh, according to the Swedish Energy Agency [2]. Electricity and oil represent $50 \%$ and $8 \%$ of the final energy use in the residential and services sector, respectively. Substituting oil and electricity as sources of energy for heating systems with efficient use of resources via district heating $(\mathrm{DH})$ is, therefore, vital in order to achieve a sustainable energy system in the building sector. DH is a heat distribution system where heat is produced at a central plant and distributed via the $\mathrm{DH}$ system to end-users. It is common to cogenerate the production of heat with electricity production, i.e., combined heat and power plant (CHP). Benefits from DH include the possibility to use different fuels, using waste that would otherwise be sent to landfill, cogeneration with electricity production, energy security and high supply security. 
The profitability and environmental performance of a DH system are directly connected to the buildings' energy use within the DH system. In Sweden, DH represents 32\% of the final energy use in the residential and services sector [2], and there is a significant potential to increase its share. However, future heat loads in DH systems are complex to predict, due to, among other aspects, the degree of energy renovations in the building stock. Strong incentives exist for building owners to perform building energy renovation in the form of economic savings and environmental benefits [3]. From an energy savings perspective, it is especially important to study the historic building stock because of the generally poorer thermal performance of older buildings compared to newer ones [4]. An example of investigating the energy savings potential in historic building districts includes the work presented in Liu et al. [5] using the historic district in Visby, Sweden, as a case study. The district was connected to the municipality's DH system. A combination of building categorization and life cycle cost (LCC optimization) was used. The results showed a possible decrease of $31 \%$ in energy use and LCC when targeting LCC optimum. It is important to note that no investigation was performed for the effects on the surrounding DH system from the suggested renovation measures. By implementing energy efficiency measures (EEMs) in the buildings, the heat demand will be reduced in the DH system, which is counterproductive for the DH supplier. On the other hand, EEMs could also be a beneficial measure for the DH supplier by reducing the utilization of peak load plants during wintertime, with a high operation cost on these days [6]. As a result, the economic and environmental influences on a DH system from performing building energy renovation are complex to predict because of varying local conditions in terms of fuel mix, CHP plant, heat-only production boiler etc. In addition, to overcome difficulties during studies of complex energy systems, such as cities, there is a need for efficient and rational use of computational software [7].

There are a number of scientific investigations addressing the impacts on the local energy systems from building energy renovation. Åberg and Widén [8] investigated the impact of implementing assumed EEMs in residential buildings in six different DH systems in Sweden. This was performed using a cost-optimization model structure. It was stated that a decrease in heat demand, due to energy efficiency in residential buildings results in reduced use of fossil fuels and biomass in the DH system. Moreover, it was found that the decrease and reduction of heat demand, as a result of the implementation of EEMs, mainly affect heat-only production boiler. In fact, in five out of six DH systems, the quantity of CHP-generated electricity per unit of produced heat is improved. The same cost-optimization tool was used during an investigation of the entire Swedish DH sector based on four pre-defined DH systems [9]. The four DH systems were used to describe a DH sector in aggregated form. The objective was to investigate the effects of reductions in heat demand, due to building energy efficiency improvement. It was concluded that heat demand reductions, for the most part, decrease global $\mathrm{CO}_{2}$ emissions and the use of biomass and fossil fuels. However, to maximize the reduction in $\mathrm{CO}_{2}$ emissions, the heat production technologies in different $\mathrm{DH}$ systems should be taken into account. Lundström and Wallin [10] also highlighted that by decreasing heat demand through the insulation of the building envelope, the heat load curve is levelled out, resulting in decreased greenhouse gas emissions and improved energy efficiency. The study object consisted of two multi-family buildings in Eskilstuna, Sweden, from the 1960s and 1970s. Le Truong et al. [11] investigated the effects of heat- and electricity-saving measures in multistory concrete-framed and wood-framed versions of an existing residential building connected to DH in Växjö, Sweden. The measures included domestic hot water reduction, improved building thermal envelope, ventilation heat recovery and higher household appliance efficiency. Energy savings from these measures were calculated using building energy simulation (BES) software. It was concluded that measures that decrease more peak load production also give higher primary energy savings. The largest primary energy savings were obtained from efficient household appliances. The importance of decreasing electricity use to reduce primary energy use is in line with the findings from Lidberg et al. [12], which are based on systematic studies of the energy renovation of a multi-family house connected to the DH system. Environmental benefits in the form of decreased global $\mathrm{CO}_{2}$ emissions from electricity savings were also found by Difs et al. [13], 
together with economic benefits for the local energy system. The investigation was performed using an energy system optimization model where the energy conservation measures were implemented one at a time, with the town of Linköping, Sweden, as a case study. Åberg and Henning [6] also studied the DH network in Linköping using an energy system optimization model, with a focus on impacts from energy savings in existing residential buildings built during the period 1961-1980. It was concluded that reductions in heat demand in the studied building stock result in decreased global use of fossil fuels and global $\mathrm{CO}_{2}$ emissions, which is in accordance with the results of Difs et al. [13] (based on a similar model of the DH system in Linköping). It was also shown that it is primarily heat-only production that decreases when the heat demand is reduced, which supports the results from Åberg and Widén [8]. A similar study was performed by Lidberg et al. [14] using the city of Borlänge, also situated in Sweden, as a case study where four energy efficiency packages were investigated. The results showed that electricity production decreases, due to building energy renovation, with less electricity imported to the market as a result. In addition, it was concluded that global greenhouse gas emissions are decreased for all packages, because of the assumption that biomass is a possible replacement for fossil fuels elsewhere.

As presented above, there are a number of scientific investigations addressing the impacts on the $\mathrm{DH}$ system from building energy renovation. However, research on the effects of the cost-optimal energy renovation of a building district with regard to the consequential impact on the local energy systems is scarce. The objective of this study is to present a systematic approach with a systematic perspective when investigating the impact of cost-optimal energy renovation of a historic building district concerning economics and environmental performance in terms of primary energy use and $\mathrm{CO}_{2}$ emissions on the DH system. A novel combination of building categorization, LCC optimization, -BES and energy system optimization procedures is the foundation for the proposed research. The approach is applicable for aggregating LCC and heating load to clusters of buildings and districts. Hence, it is possible to reflect the dynamic behavior of individual buildings, clusters and building districts before and after cost-optimal renovation, and the consequential effect on the surrounding DH system. Consequently, the contribution to the research community consists of the development of an effective and useful approach for predicting economic and environmental effects of the optimal renovation of buildings, clusters and districts connected to the $\mathrm{DH}$ system. Moreover, the present study will provide a systematic and holistic overview of the connections between building energy performance, profitability and environmental impact in terms of the $\mathrm{CO}_{2}$ emissions of a DH system located in a Northern European climate during cost-optimal building energy renovation.

\section{Systems Approach and Computational Tools}

In this study, a systematic approach is used to predict the effects of cost-optimal energy renovation of a building district on the DH system. Firstly, representative building types are obtained through categorization of a building district which is the historic district in Visby, Sweden, in the current research. The original energy use and LCCs of the building types are calculated using the LCC optimization software OPtimal Energy Retrofit Advisory-Mixed Integer Linear Program (OPERA-MILP). By using OPERA-MILP, the cost-optimal energy renovation strategy is also obtained for each building type. The renovation strategy includes cost-efficient EEMs, for example, insulation of the building envelope and window replacement, as well as airtightness. BES software IDA ICE is then used to model and simulate each building type in order to obtain the building heat demand over time and heat load duration curve for each building type, before and after energy renovation. The heat load for the various building types, as well as energy use and LCCs, can be aggregated at cluster level and district level. The heat load for the $\mathrm{DH}$ system is thereafter converted into a flexible time division suitable for larger DH systems by using the software Converter [15]. Lastly, based on the converted heat load, the effects of the energy renovations performed on the $\mathrm{DH}$ system in the form of environmental impact $\left(\mathrm{CO}_{2}\right.$ emissions and primary energy use), optimal DH production and system cost are calculated using the energy systems optimization model 
MODEST (Model for Optimisation of Dynamic Energy Systems with Time-dependent components and boundary conditions). The proposed approach is illustrated in Figure 1.

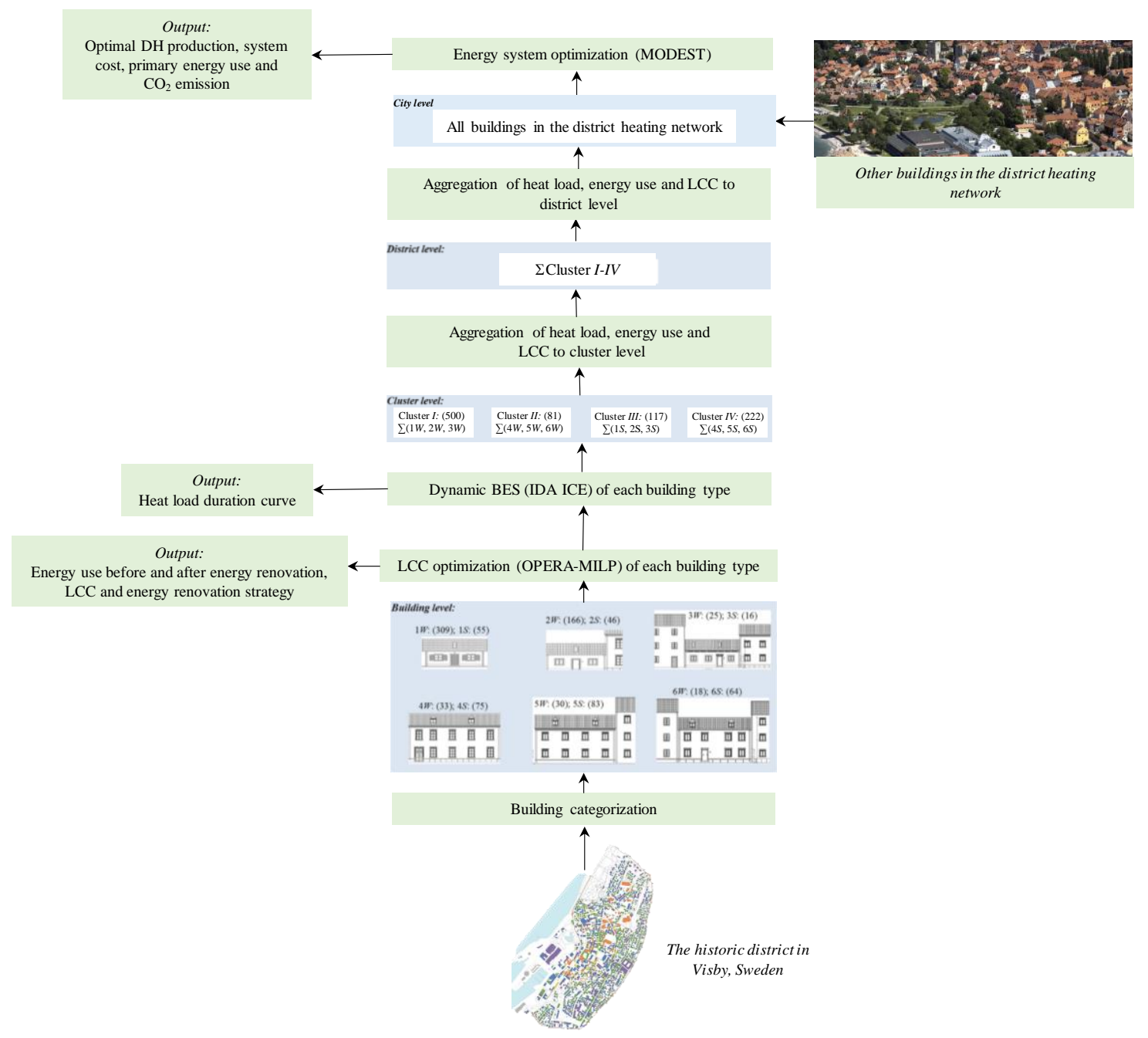

Figure 1. Schematic illustration of the proposed approach.

\subsection{Life Cycle Cost Optimization in Buildings: OPERA-MILP}

The in-house LCC optimization software OPERA-MILP is used to obtain the cost-optimal energy renovation package for the various building types. OPERA-MILP has been used successfully in a number of previous scientific investigations, e.g., [16-19]. A specified period of time is set for the optimization in the OPERA-MILP software, which is 50 years in this study. Costs related to investments in the heating system, EEMs targeting the building envelope, energy costs and maintenance costs for building components are all taken into consideration. The total LCC of a building is calculated according to Equation (1).

$$
\mathrm{LCC}_{\text {building }}=\mathrm{LCC}_{\text {investment }}+\mathrm{LCC}_{\text {energy }}+\mathrm{LCC}_{\text {maintenance }}-\mathrm{RV} \text {, }
$$

where $\mathrm{LCC}_{\text {building }}=$ total building $\mathrm{LCC}$ over the optimization period, $\mathrm{LCC}_{\text {investment }}=$ total investment costs for EEMs targeting the building envelope and heating system, $\mathrm{LCC}_{\text {energy }}=$ energy cost over the specified period of time, $\mathrm{LCC}_{\text {maintenance }}=$ maintenance cost for building components and $\mathrm{RV}=$ residual value of the investment costs connected to EEMs on the building envelope, heating system and maintenance performed on the building. 
The implemented EEMs targeting the building envelope in OPERA-MILP include replacing windows, weatherstripping, floor insulation, roof insulation and inside and outside insulation of the external walls. Concerning heating systems, $\mathrm{DH}$, groundwater heat pump, electric radiators and wood boiler are incorporated into the software. The costs for the various measures in OPERA-MILP are calculated based on cost functions, see Equations (2)-(5). The use of cost functions for describing the costs for the various measures allows for calculating a mathematical optimum, and hence, optimization of LCC.

$$
\begin{gathered}
C_{\mathrm{ws} .}=C_{1} \cdot m, \\
C_{\mathrm{w} .}=C_{2} \cdot A_{\text {window }} \\
C_{\text {i.m. }}=C_{3} \cdot A_{\mathrm{b} . \mathrm{c}}+C_{4} \cdot A_{\mathrm{b} . \mathrm{c}}+C_{5} \cdot A_{\mathrm{b} . \mathrm{c}} \cdot t, \\
C_{\text {h.s. }}=C_{6}+C_{7} \cdot P_{\text {h.s. }}+C_{8} \cdot P_{\text {h.s. }}
\end{gathered}
$$

The cost for weatherstripping is dependent on the number of windows, see Equation (2) where $C_{\text {ws. }}=$ total cost for weatherstripping, $C_{1}=$ the weatherstripping cost per window and $m=$ number of windows in the building. Meanwhile, the cost for replacing windows is dependent on the window area, see Equation (3) where $C_{\mathrm{w} .}=$ total cost for window replacement, $C_{2}=$ window replacement cost per $\mathrm{m}^{2}$ and $A_{\text {window }}=$ total window area. Equation (4) presents the cost function for the insulation measures where $C_{\text {i.m. }}=$ total cost for the insulation measure, $C_{3}=$ maintenance or inevitable cost per $\mathrm{m}^{2}, A_{\mathrm{b} . \mathrm{c}}=$ total area of the building component, $C_{4}=$ fixed part of the insulation cost per $\mathrm{m}^{2}$, $C_{5}=$ variable insulation cost per $\mathrm{m}^{2}$ depending on insulation thickness and $t=$ insulation thickness. Equation (5) shows the cost function for the installation of a heating system. $C_{\text {h.s. }}=$ total installation cost for the heating system, $C_{6}=$ base cost for the heating system not depending on power, $C_{7}=$ cost depending on the power of the heating system, $P_{\mathrm{h} . \mathrm{s}}=$ maximum power of the heating system and $C_{8}=$ cost for piping system depending on the power of the heating system.

The building's energy balance is calculated based on a time resolution of 12 time steps where each step corresponds to a month during a year. The energy balance of the building includes heat losses in the form of transmission, ventilation and infiltration and hot water use, as well as heat gains in the form of solar gains and heat from internal sources including electrical appliances, building occupants and heat from processes, such as cooking. A utilization factor for the internal heat gains energy is also considered. The maximum heat power demand is calculated based on the preset indoor temperature, the outdoor design temperature of Visby for the specific building type and the total heat losses of the building. In addition, the power demand for domestic hot water is taken into account.

\subsection{Building Energy Simulation: IDA ICE}

IDA ICE is a commercial software program within the field of BES. The mathematical models are written in Neutral Model Format (NMF) code, enabling the user to make changes in the models. The software allows a dynamic whole-year simulation. The energy balance in IDA ICE is calculated depending on building geometry, solar radiation, internal heat loads, HVAC (heating, ventilation and air-conditioning) conditions and building construction data.

\subsection{Energy System Optimization: MODEST}

In this paper, an optimization model is known as MODEST $[9,20,21]$ is used to model and analyze the DH system in Visby, and to investigate the effects of the performed energy renovations of a historic building district on the DH system. MODEST has a flexible time division, which can reflect demand peaks and diurnal, weekly and seasonal variations in energy demand and other parameters, e.g., fuel and electricity prices. MODEST has been applied to electricity and DH systems for approximately 50 local utilities [22-24]. The model has been used in numerous scientific investigations, e.g., [6,13,14,25-29]. A thorough description of MODEST is given by Henning [29] and Henning et al. [24]. 
With the use of MODEST it is possible to calculate the net income of the DH system, see Equation (6).

$$
\text { Net income }_{\mathrm{DH} \text { system }}=\mathrm{DH} \text { income-System cost, }
$$

where Net income $e_{\mathrm{DH} \text { system }}=$ net income over the optimization period for the DH system, $\mathrm{DH}$ income $=$ income for sold $\mathrm{DH}$ to end-users and System cost $=$ total cost for the optimal DH production. It should be noted that only costs connected to the optimal DH production are considered, and not other expenditures for running the DH system such as employee salaries.

\section{Description of the Historic District and the District Heating System in Visby}

\subsection{The Historic District}

Visby is a town located in southeastern Sweden on the island of Gotland, about $100 \mathrm{~km}$ east of the mainland in the Baltic Sea, with approximately 24,000 inhabitants. The average annual outdoor temperature in Visby is $+7.7^{\circ} \mathrm{C}$. Twelve historic residential building types, which are typical historic buildings in Visby, are selected as the study object [30,31]. The building types are obtained based on a categorization study of the historic district of Visby. The categorization method can be divided into three main steps:

1. Inventory of the building stock, i.e., gathering and compilation of building data;

2. Categorization (allocating buildings in groups depending on the number of adjoining walls, number of stories and floor area);

3. Selection of building types that are representative of the building stock (each building type selected based on average values of various building characteristics).

The categorization method resulted in a total of 12 building types: $1 W-6 W$ and $1 S-6 S$ (" $W$ " indicating a building structure of wood and " $S$ " indicating a building structure of stone). Building types $1 W-3 W$ and $1 S-3 S$ represent single-family houses with one story and a heated attic floor, and building types $4 \mathrm{~W}-6 \mathrm{~W}$ and $4 S-6 S$ multi-family buildings with two stories and a heated attic floor. Moreover, other differences between the building types include building thermal envelope performance, basement type, adjoining walls, etc. The building types are illustrated in Figure 2 where a photograph of the corresponding building category is also shown below each illustration. Building category 1 is seen in the top left corner, building category 2 in the top center and so forth.

Using the 12 building types described above, Liu et al. [5] formed four clusters based on variations in building size and type of building structure. Single-family houses $1 W-3 W$ formed Cluster $I$, multi-family buildings $4 \mathrm{~W}-6 \mathrm{~W}$ Cluster II, single-family houses $1 S-3 S$ Cluster III and multi-family buildings $4 S-6 S$ Cluster $I V$. Cluster $I$ includes 500 similar single-story wood buildings, Cluster II 81 similar multi-story wood buildings, Cluster III 117 similar single-story stone buildings and Cluster IV 222 similar multi-story stone buildings. Construction data for the building types is given in Table 1 , as well as the number of buildings in each cluster. In all building types, the majority of the window area faces east and west from the building, with double-glazed windows. All building types are naturally ventilated. The indoor temperature is set to $21^{\circ} \mathrm{C}$ following the recommendations by the Public Health Agency of Sweden [32]. Internal heat generation and domestic hot water use are estimated using data from Sveby, a development program for companies and organizations in the construction and real estate industry. The use of domestic hot water is differentiated whether the building is a single-family house (Cluster I and Cluster III) or a multi-family building (Cluster II and Cluster IV). 


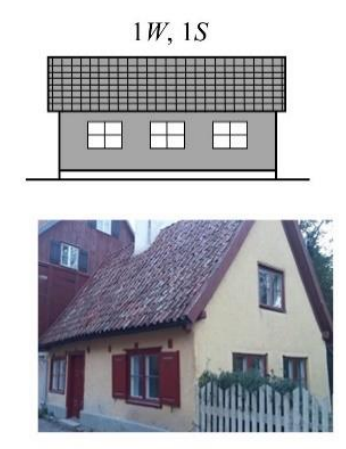

$4 W, 4 S$
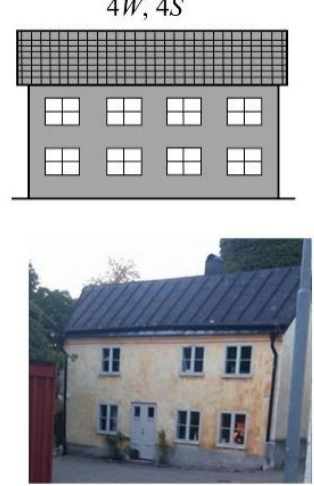

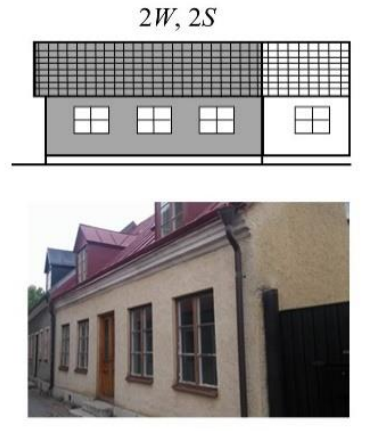

$5 W, 5 S$
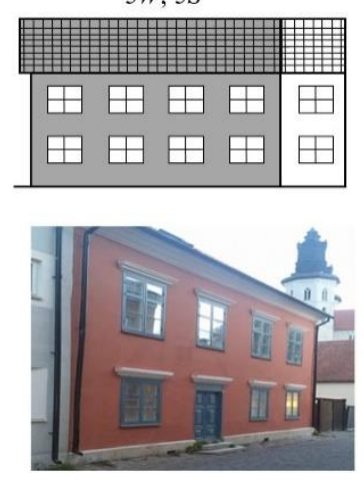

$3 W, 3 S$
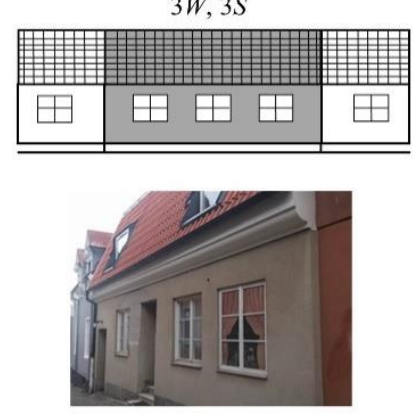

$6 W, 6 S$
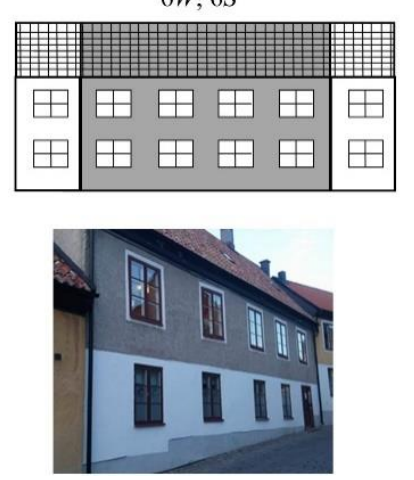

Figure 2. The studied building types with photographs of corresponding building categories.

Table 1. The number of buildings in each cluster and construction data for the building types.

\begin{tabular}{|c|c|c|c|c|c|c|c|c|c|c|c|c|c|}
\hline \multirow{2}{*}{\multicolumn{2}{|c|}{$\begin{array}{c}\text { Cluster } \\
\text { Building Type }\end{array}$}} & \multicolumn{3}{|c|}{$I$} & \multicolumn{3}{|c|}{ II } & \multicolumn{3}{|c|}{ III } & \multicolumn{3}{|c|}{$I V$} \\
\hline & & $1 W$ & $2 W$ & $3 W$ & $4 W$ & $5 W$ & $6 W$ & $1 S$ & $2 S$ & $3 S$ & $4 S$ & $5 S$ & $6 S$ \\
\hline \multicolumn{2}{|c|}{ No. of Buildings } & 309 & 166 & 25 & 33 & 30 & 18 & 55 & 46 & 16 & 75 & 83 & 64 \\
\hline \multirow{2}{*}{ Building structure } & Wood & $x$ & $x$ & $x$ & $x$ & $x$ & $x$ & & & & & & \\
\hline & Stone & & & & & & & $x$ & $x$ & $x$ & $x$ & $x$ & $x$ \\
\hline \multirow{2}{*}{ Basement type } & Crawl space & $x$ & $x$ & $x$ & & & & $x$ & $x$ & $x$ & & & \\
\hline & Unheated basement & & & & $x$ & $x$ & $x$ & & & & $x$ & $x$ & $x$ \\
\hline \multicolumn{2}{|c|}{ No. of adjoining walls } & 0 & 1 & 2 & 0 & 1 & 2 & 0 & 1 & 2 & 0 & 1 & 2 \\
\hline \multirow{2}{*}{ External walls } & Area $\left(\mathrm{m}^{2}\right)$ & 86 & 61 & 45 & 245 & 180 & 116 & 80 & 57 & 43 & 235 & 173 & 112 \\
\hline & $U$-value $\left(\mathrm{W} /\left(\mathrm{m}^{2} \cdot{ }^{\circ} \mathrm{C}\right)\right)$ & 0.65 & 0.65 & 0.65 & 0.67 & 0.67 & 0.67 & 1.8 & 1.8 & 1.8 & 1.97 & 1.97 & 1.97 \\
\hline \multirow{2}{*}{ Windows } & Area $\left(\mathrm{m}^{2}\right)$ & 12 & 12 & 12 & 44 & 37 & 30 & 12 & 12 & 12 & 44 & 37 & 30 \\
\hline & $U$-value $\left(\mathrm{W} /\left(\mathrm{m}^{2} \cdot{ }^{\circ} \mathrm{C}\right)\right)$ & 2.9 & 2.9 & 2.9 & 2.9 & 2.9 & 2.9 & 2.9 & 2.9 & 2.9 & 2.9 & 2.9 & 2.9 \\
\hline \multirow{2}{*}{ Roof } & Area $\left(\mathrm{m}^{2}\right)$ & 71 & 79 & 92 & 170 & 159 & 159 & 65 & 73 & 86 & 161 & 150 & 150 \\
\hline & $U$-value $\left(\mathrm{W} /\left(\mathrm{m}^{2} \cdot{ }^{\circ} \mathrm{C}\right)\right)$ & 0.18 & 0.18 & 0.18 & 0.25 & 0.25 & 0.25 & 0.18 & 0.18 & 0.18 & 0.25 & 0.25 & 0.25 \\
\hline \multirow{2}{*}{ Floor } & Area $\left(\mathrm{m}^{2}\right)$ & 49 & 50 & 58 & 133 & 124 & 129 & 44 & 44 & 52 & 123 & 115 & 120 \\
\hline & $U$-value $\left(\mathrm{W} /\left(\mathrm{m}^{2} \cdot{ }^{\circ} \mathrm{C}\right)\right)$ & 1.10 & 1.10 & 1.10 & 0.23 & 0.23 & 0.23 & 1.10 & 1.10 & 1.10 & 0.23 & 0.23 & 0.23 \\
\hline \multicolumn{2}{|l|}{ Heated area $\left(\mathrm{m}^{2}\right)$} & 98 & 100 & 116 & 398 & 372 & 387 & 87 & 88 & 104 & 369 & 345 & 360 \\
\hline \multicolumn{2}{|l|}{ Heated volume $\left(\mathrm{m}^{3}\right)$} & 216 & 219 & 256 & 942 & 881 & 917 & 192 & 194 & 228 & 874 & 817 & 852 \\
\hline \multicolumn{2}{|c|}{ Air change rate $(\mathrm{ACH})$} & 0.76 & 0.74 & 0.72 & 0.65 & 0.64 & 0.62 & 0.77 & 0.75 & 0.73 & 0.65 & 0.64 & 0.62 \\
\hline
\end{tabular}

To investigate the impact from cost-optimal energy renovation of a historic building district on the DH system in Visby, three different cases concerning LCC and building energy use are investigated. $\mathrm{DH}$ is set as the default heating system in all cases. To enable an assessment of the effects of energy renovation, a reference case for the studied buildings is modelled. The remaining lifetime of the building components is set to 0 years in all cases. In Case 1 (the reference case), no EEMs on the building 
envelope are allowed. DH is set as the default heating system since it is the most common heating form in Sweden and is available in Visby. In Case 2 (LCC optimum), the lowest LCC is obtained by selecting cost-effective EEMs on the building envelope. In Case 3, specific energy targets are achieved for the studied building types $\left(83 \mathrm{kWh} / \mathrm{m}^{2}\right.$ and $79 \mathrm{kWh} / \mathrm{m}^{2}$ for the single-family houses and multi-family buildings, respectively) according to Swedish building regulations, BBR. It should be noted that the energy targets vary depending on geographical location and heating system type in BBR. The location of Visby and DH as the preset heating system are, therefore, considered for the energy targets in Case 3 . The cases included in this investigation are summarized in Table 2.

Table 2. Summary of the investigated cases in this study. LCC, life cycle cost.

\begin{tabular}{lcc}
\hline \multicolumn{1}{c}{ LCC/Energy Target } & EEMs on the Building Envelope & Case No. \\
\hline Reference & Not allowed & Case 1 \\
\hline LCC optimum & Allowed & Case 2 \\
\hline $\begin{array}{l}\text { Swedish building regulations }-83 \mathrm{kWh} / \mathrm{m}^{2} \text { and } 79 \mathrm{kWh} / \mathrm{m}^{2} \text { for } \\
\text { single-family houses and multi-family buildings, respectively }\end{array}$ & Allowed & Case 3 \\
\hline
\end{tabular}

\subsection{The District Heating System}

Heat generation is carried out by energy utilities which belong to Gotlands Energi AB (GEAB), the municipal energy utility for Visby. GEAB provides approximately $185 \mathrm{GWh} /$ year (normal year corrected using Energy-Index from the Swedish Meteorological and Hydrological Institute (SMHI) heat to approximately 1250 end-users through the DH distribution network. The end-users of heat, i.e., the customers, can be small single-family houses, large multi-family buildings or various types of public buildings, such as libraries and schools. The total length of the DH pipe network is $90 \mathrm{~km}$, and the culvert heat losses are approximately $11 \%$. The supply temperature varies between 75 and $100{ }^{\circ} \mathrm{C}$ depending on the outdoor temperature. A schematic description of the DH system in Visby connected to end users, including Cluster I, Cluster II, Cluster III and Cluster IV, with heat production facilities is shown in Figure 3. The DH production is dominated by biomass. Most of the DH production takes place in heat-only biomass boilers (HOB 5, HOB 6) with flue gas condensation (FGC) together with a compressor heat pump (HP). There are also a number of heat-only peak load boilers, namely bio oil boilers (HOB 1, HOB 2, HOB 3, HOB 4), an electric boiler (HOB 8) and an oil boiler (HOB 7), which are only in operation during the winter season. On average, the heat-only bio-fuel boilers (HOB $5, \mathrm{HOB} 6$ ) produce about $90 \%$ of $\mathrm{DH}$ demand in the system. In addition, landfill gas is utilized to produce heat in the $\mathrm{DH}$ system.

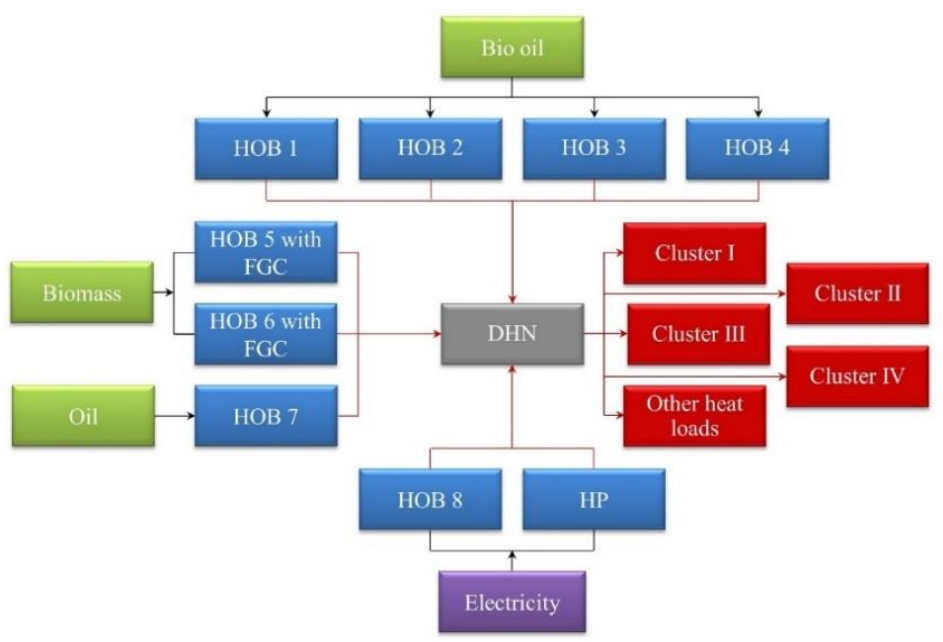

Figure 3. Schematic of the DH system in Visby. 


\section{Input Data}

\subsection{Input Data: OPERA-MILP}

The modelling in terms of building properties was based on the data presented in Section 3.1 for each building. The LCC optimization of the various building types is performed based on a time period of 50 years. The remaining lifetime of the building components is set to zero, resulting in an inevitable cost occurring for the various building elements. DH is set as the heating system before and after renovation. The remaining lifetime of the DH units in the building types is set to zero.

The selection of a cost-optimal energy renovation strategy is directly dependent on the input data used in the OPERA-MILP software. Costs for the various EEMs incorporated into OPERA-MILP are analyzed using cost functions in OPERA-MILP, see Section 2.1. The cost functions are developed based on the Swedish database Wikells [33], which provides up-to-date market costs, as well as using manufacturer data. The investment costs for the various EEMs are given in Table 3. Since the twelve building types include buildings with a structure of either wood or stone, investment costs are developed for both building structures. The minimum insulation thickness is set to $2 \mathrm{~cm}$ and the maximum to $42 \mathrm{~cm}$ with a step resolution of $2 \mathrm{~cm}$. The thermal conductivity of additional insulation is $0.037 \mathrm{~W} /\left(\mathrm{m} \cdot{ }^{\circ} \mathrm{C}\right)$. In addition, the cost for weatherstripping varies depending on whether the building is a single-family house or a multi-family building. This is because of a difference in window size. The estimated $U$-values for the windows are $1.5 \mathrm{~W} /\left(\mathrm{m}^{2} .{ }^{\circ} \mathrm{C}\right), 1.2 \mathrm{~W} /\left(\mathrm{m}^{2} \cdot{ }^{\circ} \mathrm{C}\right)$ and $0.8 \mathrm{~W} /\left(\mathrm{m}^{2} .{ }^{\circ} \mathrm{C}\right)$ for the double-glazed, triple-glazed and triple-glazed + low emission windows, respectively. It should be noted that window replacement is inevitable in Case 2 and Case 3. However, since no EEMs are allowed in the reference case, see Table 2, a maintenance cost for the windows is included corresponding to the investment cost for the double-glazed windows. The lifetime is set at 50 years for all insulation measures and 30 years for windows [34]. The lifetime for weatherstripping is assumed to be 10 years.

Table 3. Investment cost for the energy efficiency measures (EEMs).

\begin{tabular}{|c|c|c|c|c|c|c|c|c|}
\hline EEMs & $\begin{array}{l}C_{1, \mathrm{SFH}}{ }^{1} / \mathrm{MFB}^{2} \\
\text { (SEK/Window) }\end{array}$ & $\begin{array}{c}C_{2, \mathrm{DG}^{3} / \mathrm{TG}^{4} / \mathrm{TG}+\mathrm{LE}}{ }^{5} \\
\left(\mathrm{SEK} / \mathrm{m}^{2} \text { Window) }\right.\end{array}$ & $\begin{array}{c}C_{3, \text { wood} / \text { stone }} \\
\left(\mathrm{SEK} / \mathrm{m}^{2}\right)\end{array}$ & $\begin{array}{c}C_{4, \text { wood } / \text { stone }} \\
\left(\mathrm{SEK} / \mathrm{m}^{2}\right)\end{array}$ & $\begin{array}{l}C_{5, \text { wood/stone }} \\
\left(\mathrm{SEK} / \mathrm{m}^{2} \cdot \mathrm{m}\right)\end{array}$ & $\begin{array}{c}C_{6} \\
(\mathrm{SEK})\end{array}$ & $\begin{array}{c}C_{7} \\
(\mathrm{SEK} / \mathrm{kW})\end{array}$ & $\begin{array}{c}C_{8} \\
(\mathrm{SEK} / \mathrm{kW})\end{array}$ \\
\hline Weatherstripping & $441 / 617$ & - & - & - & - & - & - & - \\
\hline $\begin{array}{l}\text { Window } \\
\text { replacement }\end{array}$ & - & $6738 / 8492 / 12,169$ & - & - & - & - & - & - \\
\hline Roof insulation & - & - & $0 / 0$ & $0 / 0$ & $679 / 679$ & - & - & - \\
\hline Floor insulation & - & - & $0 / 0$ & $242 / 242$ & 799/799 & - & - & \\
\hline $\begin{array}{l}\text { External wall } \\
\text { inside insulation }\end{array}$ & - & - & $153 / 153$ & $908 / 1335$ & $1267 / 1267$ & - & - & - \\
\hline $\begin{array}{l}\text { External wall } \\
\text { outside insulation }\end{array}$ & - & - & $407 / 407$ & $2411 / 2571$ & $1267 / 1267$ & - & - & - \\
\hline DH unit & - & - & - & - & - & 22,611 & 415 & 255 \\
\hline
\end{tabular}

${ }^{1} \mathrm{SFH}=$ single-family house,${ }^{2} \mathrm{MFB}=$ multi-family building,${ }^{3} \mathrm{DG}=$ double-glazed,${ }^{4} \mathrm{TG}=$ triple-glazed and ${ }^{5} \mathrm{TG}+$ $\mathrm{LE}=$ triple-glazed + low emission glass.

The exchange rate is set to 10.30 SEK $\approx 1$ Euro [35]. A discount rate of $5 \%$ is used [36]. For piping system in the heating systems, a lifetime of 50 years is set. Data concerning fuel prices, annual cost, life times and efficiencies connected to the DH unit is presented in Table 4. Fuel prices and annual costs for DH are obtained from Gotlands Energi AB using data from 2016.

Table 4. Price data, life time and efficiency for the DH unit.

\begin{tabular}{ccccc}
\hline Heating System Data & Fuel Price (SEK/MWh) & Annual Cost (SEK) & $\eta$ (-) & Life Time (Years) \\
\hline DH unit & 959 & 315 & 0.95 & $25[37]$ \\
\hline
\end{tabular}

\subsection{Input Data: IDA ICE}

In the present study, version 4.8 of IDA ICE was used. The buildings were modeled using climate data based on ASHRAE IWEC2 [38]. Each building was modelled based on the data presented in 
Section 3.1. The simulations were performed during one year with 14 days of dynamic startup in order to achieve stability in the thermal characteristics of the building, such as the set indoor temperature, which is also the default in the software. IDA ICE models visualizing each building category are seen in Figure 4. Building category 1 is seen in the top left corner, building category 2 in the top center, and so forth.
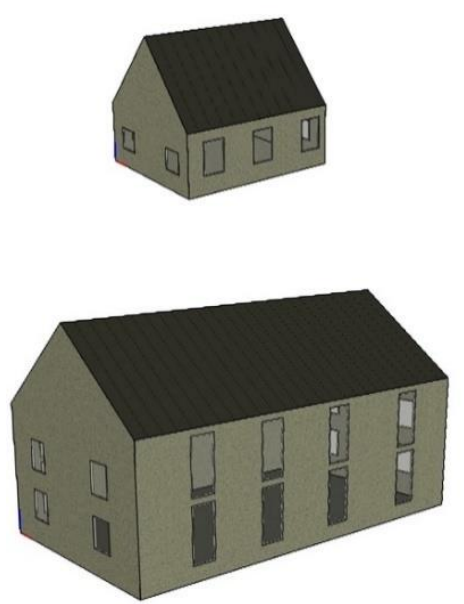
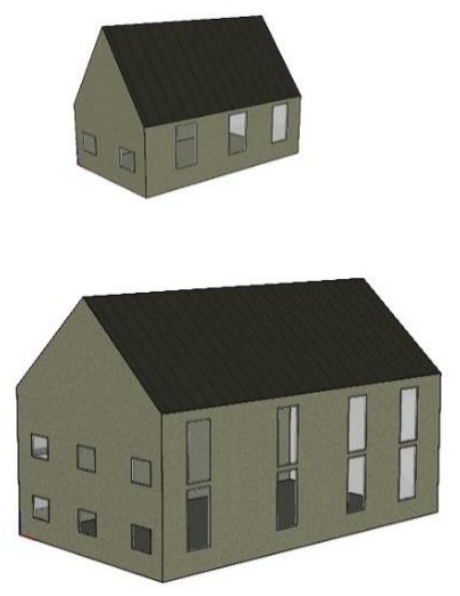
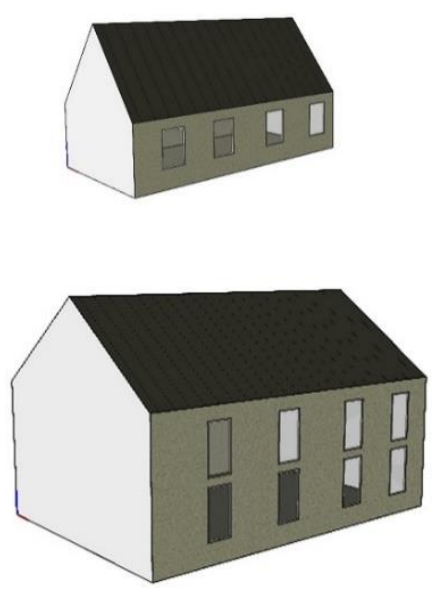

Figure 4. The buildings modeled in IDA ICE software.

\subsection{Input Data: MODEST}

The DH system in Visby is modeled in MODEST. Technical data for utilities, $\mathrm{CO}_{2}$ emission factors and flexible time divisions that can reflect peaks and diurnal, weekly and seasonal variations in $\mathrm{DH}$ demand in Visby are given as input data for MODEST, see Table 5. The DH demand ( $185 \mathrm{GWh} /$ year) varies continuously throughout weekdays, weekends and months. Table 6 shows the MODEST time periods used in this study. $\mathrm{CO}_{2}$ emission factors for the fuel used in the $\mathrm{DH}$ model include both production and transportation. The electricity prices in the model reflect the average value of the actual Swedish electricity prices on the Nord Pool spot market during 2018 for Visby including electricity distribution costs and electricity tax. A period of 50 years is studied, and the discount rate is set to $5 \%$. The primary energy factor for the DH produced in Visby is set as 0.31 since this is the local value [39].

Table 5. DH production plants and their properties.

\begin{tabular}{|c|c|c|c|}
\hline Heat-Only Boilers/Heat Pump & Heat Production (MW) & Fuel & $\begin{array}{c}\mathrm{CO}_{2} \text { Emission Factor } \\
{[40,41]\left(\mathrm{g} \mathrm{CO}_{2 \text { eq. }} / \mathrm{kWh}\right)}\end{array}$ \\
\hline HOB 1 & 27.2 & Bio oil & 5 \\
\hline НOB 2 & 10.8 & Bio oil & 5 \\
\hline HOB 3 & 6 & Bio oil & 5 \\
\hline HOB 4 & 11.8 & Bio oil & 5 \\
\hline HOB 5 with FGC ${ }^{1}$ & 10 & Biomass & 11 \\
\hline HOB 6 with FGC ${ }^{1}$ & 18 & Biomass & 11 \\
\hline HOB 7 & 6.6 & Oil & 290 \\
\hline HOB $8^{2}$ & 17 & Electricity & 969 \\
\hline Heat pump $(\mathrm{HP})^{3}$ & 12 & Electricity & 969 \\
\hline
\end{tabular}


Table 6. The MODEST-time periods applied in this study.

\begin{tabular}{clcl}
\hline Month & \multicolumn{1}{c}{ Days and Hours } & Month & \multicolumn{1}{c}{ Days and Hours } \\
\hline November-March & Mon.-Fri., 6-7 & April-October & Mon.-Fri., 6-22 \\
& Mon.-Fri., 7-8 & & Mon.-Fri., 22-6 \\
& Mon.-Fri., 8-16 & & Sat., Sun. and holiday, 6-22 \\
& Mon.-Fri., 16-22 & & Sat., Sun. and holiday, 22-6 \\
& Mon.-Fri., 22-6 & & \\
& Sat., Sun. and holidays, 6-22 & & \\
& Sat., Sun. and holidays, 22-6 & \\
& Top day, 6-7 & \\
& Top day, 7-8 & \\
& Top day, 8-16 & \\
& Top day, 16-22 & \\
& Top day, 22-6 & \\
\hline
\end{tabular}

The DH production is dominated by biomass. Most of the $\mathrm{DH}$ production takes place in heat-only biomass boilers (HOB 5, HOB 6) with flue gas condensation (FGC) together with a compressor heat pump (HP). There are also a number of heat-only peak load boilers, namely bio oil boilers (HOB 1 , HOB 2, HOB 3, HOB 4), an electric boiler (HOB 8) and an oil boiler (HOB 7), which are only in operation during the winter season. On average, the heat-only bio-fuel boilers (HOB 5, HOB 6) produce about $90 \%$ of $\mathrm{DH}$ demand in the system.

The marginal electricity production accounting model has been used in order to calculate global $\mathrm{CO}_{2}$ emissions. This means that a coal-fired condensing power plant has been assumed to be the short-term marginal power plant in the European electricity system. According to marginal electricity, the production of $1 \mathrm{GWh}$ electricity gives 969 metric ton of $\mathrm{CO}_{2 \mathrm{eq}}$. [40]. Hence, the local electricity used, e.g., for heat pumps, will increase the electricity produced by coal-fired condensed power plants and that the global $\mathrm{CO}_{2}$ emissions will, therefore, increase.

\section{Results and Discussion}

\subsection{Energy Use, LCC, and System Cost, Net Income and Environmental Effects of the DH System before} Energy Renovation of the Studied Buildings in Visby

The following section presents energy use and LCC for the buildings before energy renovation. This is shown at building type level, cluster level and district level. In addition, the environmental effects and system cost are given at city level together with the total net income for the DH system.

\subsubsection{Building Level}

The original performance of the building types in terms of specific energy use and LCC has been predicted using OPERA-MILP. Energy use and LCC for the various building types are presented in Table 7. The specific energy varies between 99.1 and $200.1 \mathrm{kWh} / \mathrm{m}^{2}$ for the wood buildings and between 143.2 and $324.0 \mathrm{kWh} / \mathrm{m}^{2}$ for the stone buildings. The overall better thermal performance of the wood buildings compared to the stone buildings, as a result of the lower $U$-value of the external walls as presented in Table 1, is the reason for the lower energy use in the wood buildings. It should be noted that the specific energy use (heating and domestic hot water use) for buildings built before 1940 in Sweden is on average $125 \mathrm{kWh} / \mathrm{m}^{2}$ for single-family houses and $146 \mathrm{kWh} / \mathrm{m}^{2}$ for multi-family buildings [42]. This means that all single-family houses in this study have higher energy use (in the range of $161.2-324.0 \mathrm{kWh} / \mathrm{m}^{2}$ ) compared to the national average. The opposite trend is seen with the multi-family buildings, where the buildings in Cluster II, i.e., building types $4 \mathrm{~W}-6 \mathrm{~W}$, and building type $6 S$ have a lower specific energy use (varying between 99.1 and $143.2 \mathrm{kWh} / \mathrm{m}^{2}$ ) compared to the Swedish average. 
Table 7. Maximum building power demand, specific energy use and LCC for the various building types.

\begin{tabular}{lllllllllllll}
\hline \multicolumn{1}{c}{ Cluster } & \multicolumn{1}{c}{$\boldsymbol{I}$} & & & $\boldsymbol{I I}$ & \multicolumn{3}{c}{$\boldsymbol{I I I}$} & \multicolumn{3}{c}{$\boldsymbol{I V}$} \\
\hline \multicolumn{1}{c}{ Building Type } & $\mathbf{1 W}$ & $\mathbf{2 W}$ & $\mathbf{3 W}$ & $\mathbf{4 W}$ & $\mathbf{5 W}$ & $\mathbf{6 W}$ & $\mathbf{1 S}$ & $\mathbf{2 S}$ & $\mathbf{3 S}$ & $\mathbf{4 S}$ & $\mathbf{5 S}$ & $\mathbf{6 S}$ \\
\hline Maximum power demand $(\mathrm{kW})$ & 6.9 & 6.4 & 6.7 & 19.0 & 16.3 & 14.4 & 9.1 & 7.8 & 7.6 & 27.3 & 22.2 & 17.9 \\
Specific energy use $\left(\mathrm{kWh} / \mathrm{m}^{2}\right)$ & 200.1 & 178.6 & 161.2 & 128.1 & 115.4 & 99.1 & 324.0 & 266.2 & 218.0 & 219.8 & 187.3 & 143.2 \\
Specific LCC $\left(\mathrm{kSEK} / \mathrm{m}^{2}\right)$ & 5.6 & 5.0 & 4.4 & 3.7 & 3.3 & 2.7 & 8.1 & 6.8 & 5.6 & 5.5 & 4.8 & 3.6 \\
\hline
\end{tabular}

In terms of specific LCC during the optimization period of 50 years, the LCC is in the range between 2.7 and $5.6 \mathrm{kSEK} / \mathrm{m}^{2}$ (kSEK stands for thousands of SEK) for the wood buildings and between 3.6 and $8.1 \mathrm{kSEK} / \mathrm{m}^{2}$ for the stone buildings. There is a strong correlation between high/low energy use and high/low LCC. The reason for this is that the LCC before energy renovation consists only of energy cost and heating system installation cost, where the energy cost constitutes the largest expenditure of LCC by a significant degree because of the low installation cost for the building's heating system, i.e., the DH system, see Table 3.

\subsubsection{Cluster Level}

Energy use and LCC for the four building clusters are presented in Table 8. The specific energy use for the various clusters is $190.7 \mathrm{kWh} / \mathrm{m}^{2}, 117.1 \mathrm{kWh} / \mathrm{m}^{2}, 284.9 \mathrm{kWh} / \mathrm{m}^{2}$ and $185.8 \mathrm{kWh} / \mathrm{m}^{2}$ for Cluster $I$, Cluster II, Cluster III and Cluster IV, respectively. The corresponding figures are $207.1 \mathrm{kWh} / \mathrm{m}^{2}$ for all single-family houses (Cluster I and Cluster III) and $166.4 \mathrm{kWh} / \mathrm{m}^{2}$ for all multi-family buildings (Cluster II and Cluster $I V$ ), which is $82 \mathrm{kWh} / \mathrm{m}^{2}$ and $20 \mathrm{kWh} / \mathrm{m}^{2}$ above the national average for single-family houses and multi-family buildings, respectively.

Table 8. Energy use and LCC for the four building clusters before renovation.

\begin{tabular}{|c|c|c|c|c|c|c|c|c|c|c|c|c|}
\hline Cluster & & $I$ & & & II & & & III & & & $I V$ & \\
\hline Building Type & $1 W$ & $2 W$ & $3 W$ & $4 W$ & $5 W$ & $6 W$ & $1 S$ & $2 S$ & $3 S$ & $4 S$ & $5 S$ & $6 S$ \\
\hline No. of Buildings & 309 & 166 & 25 & 33 & 30 & 18 & 55 & 46 & 16 & 75 & 83 & 64 \\
\hline Specific energy use $\left(\mathrm{kWh} / \mathrm{m}^{2}\right)$ & 200.1 & 178.6 & 161.2 & 128.1 & 115.4 & 99.1 & 324.0 & 266.2 & 218.0 & 219.8 & 187.3 & 143.2 \\
\hline $\begin{array}{l}\text { Specific energy use at the cluster level } \\
\left(\mathrm{kWh} / \mathrm{m}^{2}\right)\end{array}$ & & 190.7 & & & 117.1 & & & 284.9 & & & 185.8 & \\
\hline $\begin{array}{l}\text { Total energy use at the cluster level } \\
\text { (GWh) }\end{array}$ & & 9.5 & & & 3.7 & & & 3.0 & & & 14.7 & \\
\hline Specific LCC (kSEK/m²) & 5.6 & 5.0 & 4.4 & 3.7 & 3.3 & 2.7 & 8.1 & 6.8 & 5.6 & 5.5 & 4.8 & 3.6 \\
\hline $\begin{array}{l}\text { Specific LCC at Cluster level } \\
\left(\mathrm{kSEK} / \mathrm{m}^{2}\right)\end{array}$ & & 5.3 & & & 3.3 & & & 7.2 & & & 4.7 & \\
\hline Total LCC at Cluster level (MSEK) & & 263.8 & & & 103.2 & & & 75.6 & & & 372.9 & \\
\hline
\end{tabular}

The specific LCCs during the optimization period of 50 years are $5.3 \mathrm{kSEK} / \mathrm{m}^{2}, 3.3 \mathrm{kSEK} / \mathrm{m}^{2}, 7.2$ $\mathrm{kSEK} / \mathrm{m}^{2}$ and $4.7 \mathrm{kSEK} / \mathrm{m}^{2}$ for Cluster I, Cluster II, Cluster III and Cluster $I V$, respectively. Hence, Cluster II has the lowest specific LCC (the cluster with the lowest specific energy use) and Cluster III the highest specific LCC, which is also the cluster with the highest specific energy use. Cluster II and Cluster $I V$ have moderate specific LCCs. The two clusters also have moderate specific energy use. When comparing the total LCCs of the various clusters, Cluster I and Cluster IV have total LCCs of 264 MSEK (MSEK stands for millions of SEK) and 373 MSEK, which is significantly higher compared to Cluster II (103 MSEK) and Cluster III (76 MSEK). This is largely explained by the large heated areas in these two clusters (Cluster $I \sim 49,800 \mathrm{~m}^{2}$ and Cluster $I V \sim 79,400 \mathrm{~m}^{2}$ ) compared to Cluster II and Cluster III, which have heated areas of $\sim 31,300 \mathrm{~m}^{2}$ and $\sim 10,500 \mathrm{~m}^{2}$, respectively.

Heating load duration curves for the various clusters are constructed using hourly data obtained through the energy simulations of the building types in IDA ICE, see Figure 5. The duration curve visualizes the heating load in descending order in terms of magnitude, considering the periods of time 
during which the loads occur. Therefore, the duration curve directly reflects the thermal performance of the clusters, as well as the heated area in each cluster. Consequently, Cluster $I V$ has the highest heat load followed by Cluster I, Cluster II and Cluster III. Furthermore, the duration curves also provide information about the baseload that is visualized by the lowest loads in the diagram. For Cluster $I$ to Cluster $I V$, the baseload occurs approximately between $1600 \mathrm{~h}$ and $2600 \mathrm{~h}$.
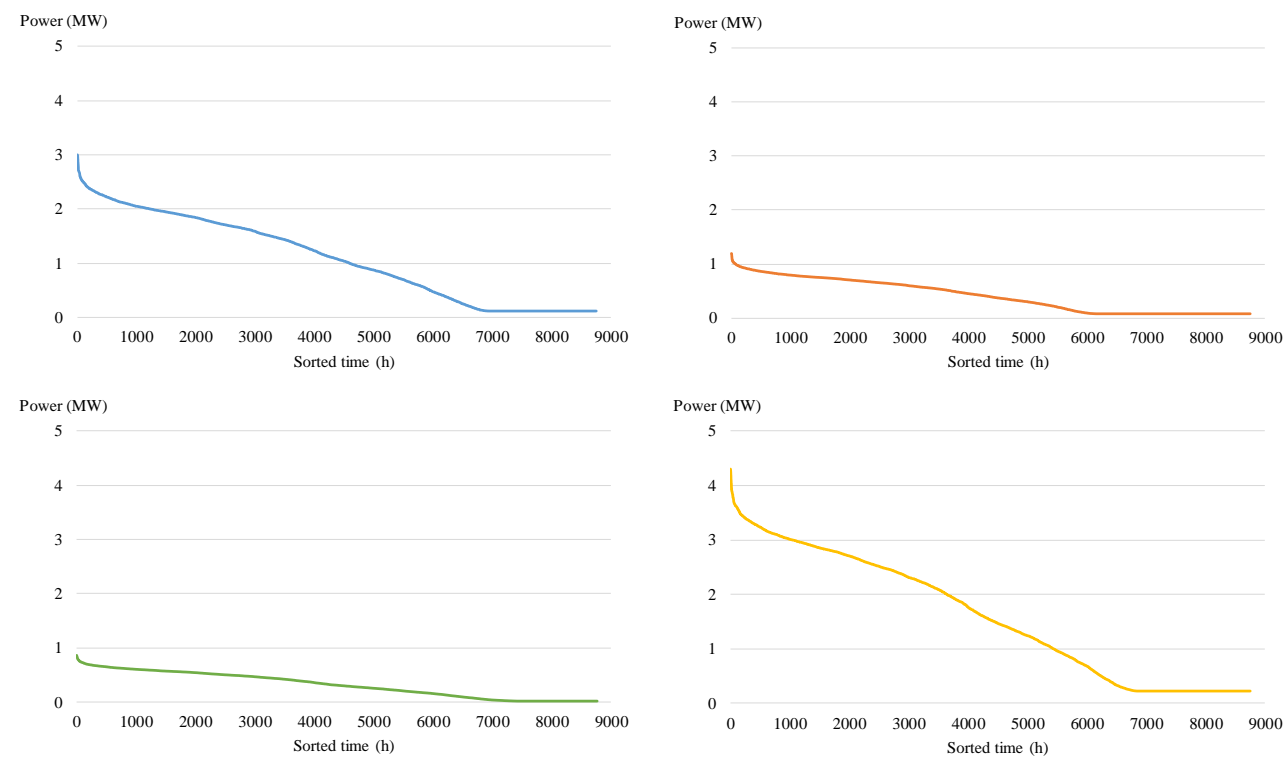

Figure 5. Duration curves for the four building clusters. Cluster $I=$ top left corner, Cluster $I I=$ top right corner, Cluster $I I I=$ bottom left corner and Cluster $I V=$ top right corner.

\subsubsection{District Level}

The total heated area before renovation for the 920 buildings in the studied district, i.e., the four building clusters, is $0.17 \mathrm{~km}^{2}$. The energy use at the district level is calculated at $31 \mathrm{GWh}$. The corresponding figure in terms of specific energy use for the district is $180.8 \mathrm{kWh} / \mathrm{m}^{2}$. The total LCC is 816 MSEK during an analysis period of 50 years, and the specific LCC is $4.8 \mathrm{kSEK} / \mathrm{m}^{2}$. The power demand over the year for the studied district and the corresponding load duration curve are shown in Figure 6. The peak load for the district is $9.4 \mathrm{MW}$, and the baseload is $0.45 \mathrm{MW}$. It is important to note that due to the monthly time-step calculation procedure in OPERA-MILP, average monthly internal heat gains are also used in IDA ICE for comparability purposes. However, a study by Milić et al. [43] showed that the predictions of energy usage correspond to a maximum annual difference of $4 \%$ when considering varying internal heat gains. The low impact from varying internal heat gains is explained by that the case study consisted of buildings with overall poor thermal performance and low time constant, similar to the buildings in the present research.
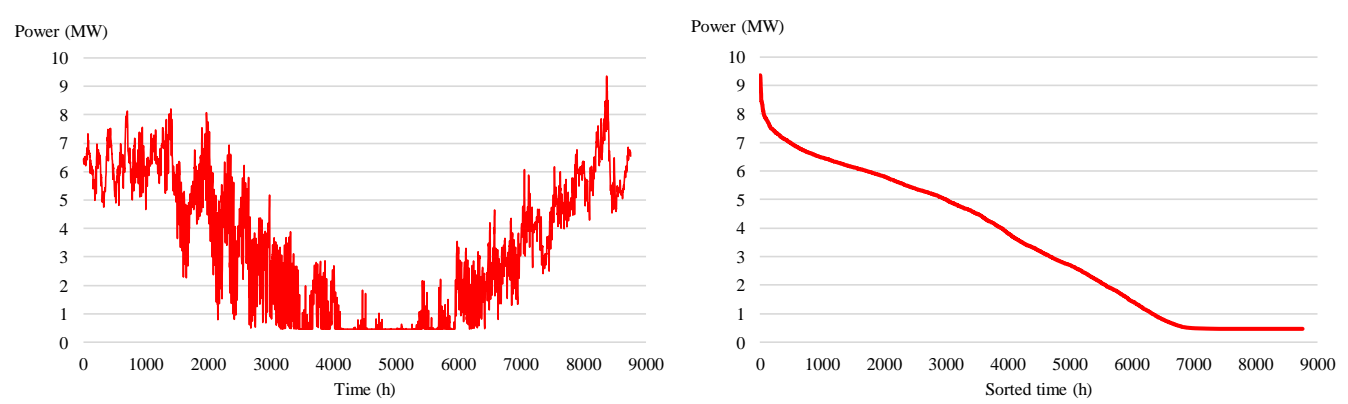

Figure 6. Power demand over the year for the building district with a corresponding duration curve. 


\subsubsection{City Level}

To enable a comparison to be made before and after cost-optimal energy renovation of the 920 buildings in the study object, the performance of the DH network in Visby before building renovation is presented in the following section. As mentioned in Section 3.2, the total DH demand before renovation is $184.6 \mathrm{GWh} /$ year for Visby. The primary energy use is $57.2 \mathrm{GWh} /$ year considering the local primary energy factor for Visby (0.31). The peak load for the city is $54 \mathrm{MW}$.

The optimal DH production by the various plants in Visby is shown in Figure 7 for Case 1 (before renovation of Clusters I-IV) using the optimization model MODEST.

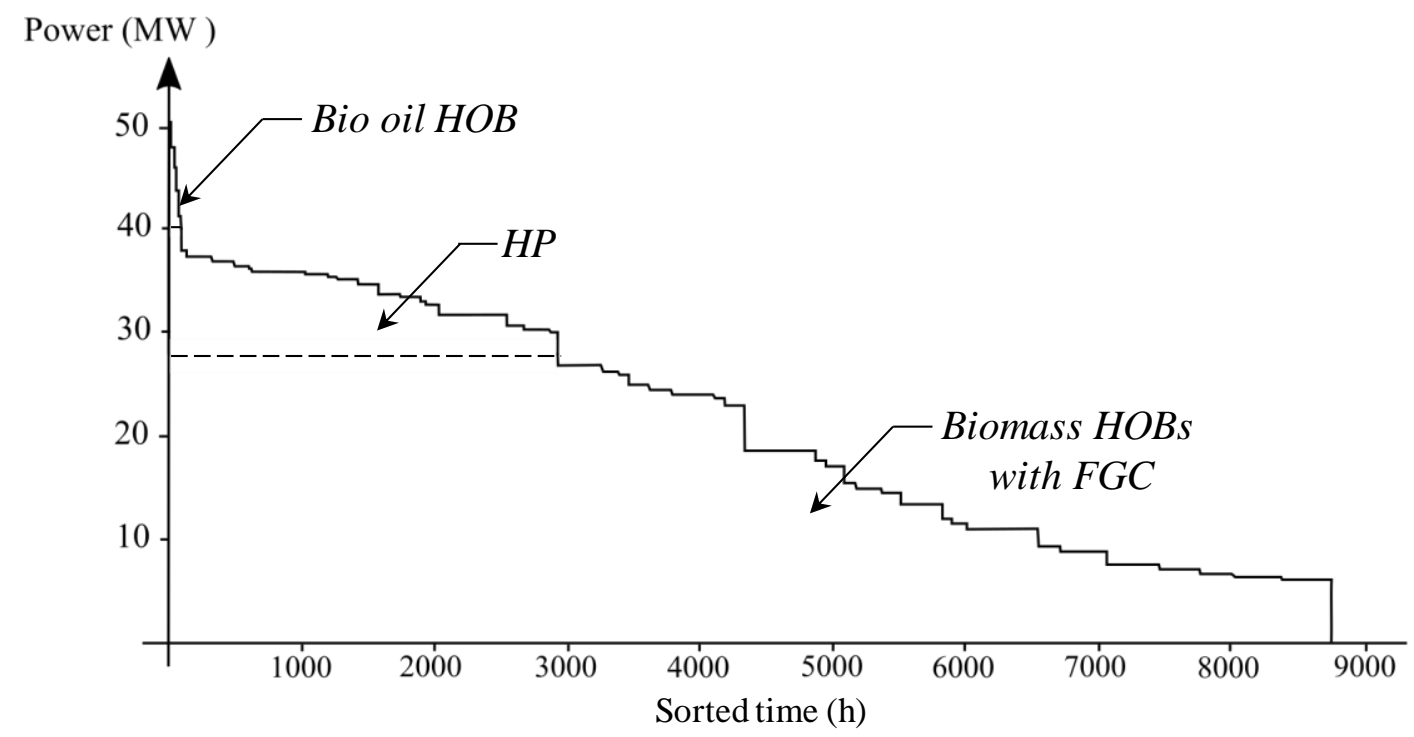

Figure 7. Optimal DH production in Visby before renovation of Clusters $I-I V$.

In Case 1 (i.e., the Reference case), no EEMs targeting the building envelope are introduced in the building stock and the $\mathrm{DH}$ demand is produced by the utilities heat-only boilers and heat pumps, see Figure 7. Biomass heat-only boilers (HOB 5, HOB 6) generate the largest part of the DH demand (164.7 GWh/year). Heat pumps additional supply heat of $18.0 \mathrm{GWh} /$ year to the DH system. The bio oil boilers produce the rest of the DH demand $(0.5 \mathrm{GWh} /$ year) during the peak load. In addition, landfill gas supplies around $1.4 \mathrm{GWh} /$ year to the $\mathrm{DH}$ system. Local and global $\mathrm{CO}_{2 e q}$. emissions, in this case, are 1667 metric ton/year and 8648 metric ton/year, respectively. The system cost for the DH system is $39.8 \mathrm{MSEK} / \mathrm{year}$ and $727 \mathrm{MSEK}$ during an optimization period of 50 years. The system cost is the present value of capital costs, fixed costs, costs related to the output power and costs associated with the amount of energy used (energy costs). The revenue from sold DH to end-users is 3232 MSEK resulting in a net income of 2505 MSEK for the DH system, or 137 MSEK/year.

\subsection{Cost-Optimal Energy Renovation; EEMs, Energy Use, LCC and System Cost, Net Income and Environmental Effects of the DH System}

This section presents the results from cost-optimal energy renovation in terms of selected EEMs, energy use and LCC for the studied cases in this investigation. This is given at building type level, cluster level and district level. Furthermore, an assessment of the effects of cost-optimal renovation on the Visby DH system in terms of system cost, net income, primary energy use and $\mathrm{CO}_{2}$ emissions is presented.

\subsubsection{Building Level}

Using LCC optimization, cost-optimal energy renovation strategies are identified for LCC optimum (Case 2) and energy targets of $83 \mathrm{kWh} / \mathrm{m}^{2}$ and $79 \mathrm{kWh} / \mathrm{m}^{2}$ for single-family houses and multi-family 
buildings, respectively, according to Swedish building energy regulations (Case 3). The selection of EEMs targeting the building envelope for the various cases is presented in Table 9. The effects of energy renovation in terms of specific energy use and LCC are given in Table 10. It is important to note that replacing windows is inevitable in Case 2 and Case 3 because the remaining lifetime of the building elements is zero, resulting in weatherstripping as a side effect, since the new windows are assumed to be airtight. From a profitability point of view, double-glazed windows are, in most cases, the suggested window type.

Table 9. Selected EEMs targeting the building envelope.

\begin{tabular}{|c|c|c|c|c|c|c|c|c|c|c|c|c|c|}
\hline \multirow{2}{*}{$\frac{\text { Cluster }}{\text { Building Type }}$} & & \multicolumn{3}{|c|}{$I$} & \multicolumn{3}{|c|}{ II } & \multicolumn{3}{|c|}{ III } & \multicolumn{3}{|c|}{$I V$} \\
\hline & & $1 W$ & $2 W$ & $3 W$ & $4 W$ & $5 W$ & $6 W$ & $1 S$ & $2 S$ & $3 S$ & $4 S$ & $5 S$ & $6 S$ \\
\hline \multirow{2}{*}{ Window type } & Case 2 & $\underset{*}{\mathrm{DG}}$ & DG & DG & DG & DG & DG & DG & DG & DG & DG & DG & DG \\
\hline & Case 3 & DG & DG & DG & DG & $\mathrm{DG}$ & DG & DG & DG & DG & DG & DG & DG \\
\hline \multirow{2}{*}{ Floor insulation } & Case 2 & 26 & 26 & 26 & 0 & 0 & 0 & 24 & 24 & 24 & 0 & 0 & 0 \\
\hline & Case 3 & 24 & 32 & 26 & 0 & 0 & 0 & 24 & 24 & 24 & 0 & 0 & 0 \\
\hline \multirow{2}{*}{ Roof insulation } & Case 2 & 12 & 12 & 12 & 18 & 16 & 16 & 10 & 10 & 10 & 16 & 16 & 16 \\
\hline & Case 3 & 10 & 18 & 4 & 24 & 24 & 6 & 0 & 0 & 0 & 16 & 16 & 10 \\
\hline \multirow{2}{*}{$\begin{array}{l}\text { External wall inside } \\
\text { insulation }\end{array}$} & Case 2 & 0 & 0 & 0 & 0 & 0 & 0 & 20 & 20 & 20 & 20 & 20 & 20 \\
\hline & Case 3 & 8 & 2 & 0 & 6 & 4 & 0 & 20 & 14 & 6 & 12 & 8 & 4 \\
\hline
\end{tabular}

Table 10. Specific energy use and LCC for the various building type. The percentage change in Case 2 and Case 3, compared to Case 1 is indicated in parentheses with an italic font.

\begin{tabular}{|c|c|c|c|c|c|c|c|c|c|c|c|c|c|}
\hline \multirow{2}{*}{\multicolumn{2}{|c|}{$\begin{array}{l}\text { Cluster } \\
\text { dilding Type }\end{array}$}} & \multicolumn{3}{|c|}{$I$} & \multicolumn{3}{|c|}{ II } & \multicolumn{3}{|c|}{ III } & \multicolumn{3}{|c|}{$I V$} \\
\hline & & $1 W$ & $2 W$ & $3 W$ & $4 W$ & $5 W$ & $6 W$ & $1 S$ & $2 S$ & $3 S$ & $4 S$ & $5 S$ & $6 S$ \\
\hline \multirow{2}{*}{ Case 1} & $\mathrm{kWh} / \mathrm{m}^{2}$ & 200.1 & 178.6 & 161.2 & 128.1 & 115.4 & 99.1 & 324.0 & 266.2 & 218.0 & 219.8 & 187.3 & 143.2 \\
\hline & $\mathrm{kSEK} / \mathrm{m}^{2}$ & 5.6 & 5.0 & 4.4 & 3.7 & 3.3 & 2.7 & 8.1 & 6.8 & 5.6 & 5.5 & 4.8 & 3.6 \\
\hline \multirow{2}{*}{ Case 2} & $\mathrm{kWh} / \mathrm{m}^{2}$ & $\begin{array}{l}111.5 \\
(-44)\end{array}$ & $\begin{array}{c}93.5 \\
(-48)\end{array}$ & $\begin{array}{c}80.2 \\
(-50)\end{array}$ & $\begin{array}{c}97.6 \\
(-24)\end{array}$ & $\begin{array}{c}88.0 \\
(-24)\end{array}$ & $\begin{array}{c}76.4 \\
(-23)\end{array}$ & $\begin{array}{c}79.3 \\
(-78)\end{array}$ & $\begin{array}{c}72.3 \\
(-74)\end{array}$ & $\begin{array}{c}67.8 \\
(-70)\end{array}$ & $\begin{array}{c}73.5 \\
(-68)\end{array}$ & $\begin{array}{c}69.1 \\
(-65)\end{array}$ & $\begin{array}{c}64.7 \\
(-56)\end{array}$ \\
\hline & $\mathrm{kSEK} / \mathrm{m}^{2}$ & $\begin{array}{c}4.3 \\
(-24)\end{array}$ & $\begin{array}{c}3.7 \\
(-26)\end{array}$ & $\begin{array}{c}3.1 \\
(-28)\end{array}$ & $\begin{array}{c}3.2 \\
(-14)\end{array}$ & $\begin{array}{c}2.9 \\
(-14)\end{array}$ & $\begin{array}{c}2.4 \\
(-14)\end{array}$ & $\begin{array}{c}5.6 \\
(-37)\end{array}$ & $\begin{array}{c}4.7 \\
(-35)\end{array}$ & $\begin{array}{c}3.8 \\
(-34)\end{array}$ & $\begin{array}{c}4.0 \\
(-32)\end{array}$ & $\begin{array}{c}3.5 \\
(-30)\end{array}$ & $\begin{array}{c}2.7 \\
(-27)\end{array}$ \\
\hline \multirow{2}{*}{ Case 3} & $\mathrm{kWh} / \mathrm{m}^{2}$ & $\begin{array}{l}81.8 \\
(-61)\end{array}$ & $\begin{array}{c}81.4 \\
(-55)\end{array}$ & $\begin{array}{c}83.1 \\
(-48)\end{array}$ & $\begin{array}{l}77.6 \\
(-41)\end{array}$ & $\begin{array}{l}75.9 \\
(-36)\end{array}$ & $\begin{array}{c}78.7 \\
(-21)\end{array}$ & $\begin{array}{c}83.1 \\
(-77)\end{array}$ & $\begin{array}{c}82.0 \\
(-71)\end{array}$ & $\begin{array}{c}82.1 \\
(-63)\end{array}$ & $\begin{array}{l}77.6 \\
(-66)\end{array}$ & $\begin{array}{c}76.9 \\
(-60)\end{array}$ & $\begin{array}{c}77.5 \\
(-46)\end{array}$ \\
\hline & $\mathrm{kSEK} / \mathrm{m}^{2}$ & $\begin{array}{c}4.7 \\
(-20)\end{array}$ & $\begin{array}{c}4.1 \\
(-18)\end{array}$ & $\begin{array}{c}3.2 \\
(-28)\end{array}$ & $\begin{array}{c}3.5 \\
(-8)\end{array}$ & $\begin{array}{c}3.2 \\
(-7)\end{array}$ & $\begin{array}{c}2.4 \\
(-13)\end{array}$ & $\begin{array}{c}5.7 \\
(-36)\end{array}$ & $\begin{array}{c}4.8 \\
(-34)\end{array}$ & $\begin{array}{c}3.9 \\
(-32)\end{array}$ & $\begin{array}{c}4.0 \\
(-31)\end{array}$ & $\begin{array}{c}3.5 \\
(-28)\end{array}$ & $\begin{array}{c}2.9 \\
(-21)\end{array}$ \\
\hline
\end{tabular}

It is important to be aware that the cost-optimal energy renovation strategy is unique for each building type because of unique building conditions in the form of layout and construction. In any case, the strategies in terms of selected insulation measures are very similar for the building types in each cluster as the building properties are highly similar. The selection of $26 \mathrm{~cm}$ floor insulation and $12 \mathrm{~cm}$ roof insulation in Case 2 for all building types in Cluster I, i.e., single-family houses in wood, is an example of this. Other trends that can be seen in Table 10 concerning selected EEMs in the building types and clusters are:

- Floor insulation in the range between $24 \mathrm{~cm}$ and $32 \mathrm{~cm}$ is profitable for Cases 2 and 3 in Cluster $I$ and Cluster III, i.e., building types standing on crawl space, because of high transmission losses originally 
- Roof insulation is generally profitable in all clusters and cases because of low retrofit costs (despite an originally low $U$-value). The suggested insulation thickness varies between 10 and $18 \mathrm{~cm}$ at LCC optimum (Case 2). The corresponding figure for the energy target according to the Swedish building regulations (Case 3) for the building types varies more, due to the cost-effective comparison between EEMs on the building envelope

- Inside insulation of the external walls is profitable for all cases in the stone buildings, Cluster III and Cluster $I V$, because of a high $U$-value before renovation, $1.80-1.97 \mathrm{~W} /\left(\mathrm{m}^{2} \cdot{ }^{\circ} \mathrm{C}\right)$. The suggested insulation thickness is $20 \mathrm{~cm}$ in Case 2, but varies between 2 and $20 \mathrm{~cm}$ in Case 3, due to the cost-effective comparison between EEMs. The inside insulation of the external walls is also necessary in some of the wooden buildings to achieve the energy targets in Case 3.

The energy use at the cost-optimum point, Case 2, varies between $80.2-111.5 \mathrm{kWh} / \mathrm{m}^{2}$, $76.4-97.6 \mathrm{kWh} / \mathrm{m}^{2}, 67.8-79.3 \mathrm{kWh} / \mathrm{m}^{2}$ and $64.7-73.5 \mathrm{kWh} / \mathrm{m}^{2}$ for Cluster I, Cluster II, Cluster III and Cluster $I V$, respectively. The percentage decrease in energy use is the highest for the building types standing on crawl space (Cluster I and Cluster III) and the building types with an external wall of stone (Cluster III and Cluster IV). The reason for this is the additional insulation of these building elements, as well as the poor $U$-value before renovation. Of the single-family houses, building type $3 W$ and all building types in Cluster III, 1S-3S, achieve the Swedish building regulations target of $83 \mathrm{kWh} / \mathrm{m}^{2}$ at the cost-optimum point. Concerning the multi-family buildings at LCC optimum, building type $6 \mathrm{~W}$, and all building types in Cluster $I V, 4 S-6 S$, achieve the energy target of $79 \mathrm{kWh} / \mathrm{m}^{2}$. Hence, the specific energy use at LCC optimum is lower than the energy target in the Swedish building regulation for all building types in stone, i.e., Cluster II and Cluster IV. In most optimizations, the energy target in Case 3 is achieved in Case 2, only requiring cost-effective comparison between the EEMs on the building envelope. This is, however, not the case in building types $1 W, 2 W, 4 W$ and $5 W$ where the energy use is further decreased in Case 3 to reach the energy target of $83 \mathrm{kWh} / \mathrm{m}^{2}$ according to the Swedish building regulations (BBR). Concerning LCC, the costs during an optimization period of 50 years are lowered by $14-37 \%$ at LCC optimum compared to before renovation. In Case 3, the LCC is lowered for all buildings compared to before renovation varying between $8 \%$ and $36 \%$. The largest percentage decrease in LCC occurs for the building types where the energy use has been decreased the most. For instance, the LCC is decreased the most in the building types in Cluster III (34-37\% at LCC optimum) which are also the building types with the highest percentage decrease in energy use (70-78\% at LCC optimum). The same tendencies are identified for the buildings with the lowest percentage decrease in energy use, $23-24 \%$ for the building types in Cluster II. The decreases in LCC are determined at $14 \%$ for the building types in Cluster II.

\subsubsection{Cluster Level}

Specific energy use and LCC in Cases 1-3 for the four building clusters are presented in Table 11, with the percentage difference after renovation (Cases 2 and 3) compared to Case 1 given in the parenthesis. The specific energy use for the various clusters varies between $69.3 \mathrm{kWh} / \mathrm{m}^{2}$ and $103.7 \mathrm{kWh} / \mathrm{m}^{2}$ in Case 2. The corresponding figures for Case 3 are 77.2 and $82.5 \mathrm{kWh} / \mathrm{m}^{2}$. The specific LCC varies between 2.9-5.0 kSEK $/ \mathrm{m}^{2}$ and 3.1-5.1 $\mathrm{kSEK} / \mathrm{m}^{2}$ for Case 2 and Case 3, respectively. Of the study's building clusters and cases, Cluster III is the cluster with the highest percentage decrease in energy use (76\%) and LCC (31\%) compared to before renovation at the cost-optimum point. Cluster II has the lowest percentage decrease in energy use (23\%), as well as in LCC (12\%). The low and high percentage decreases in energy use for Cluster II and Cluster III are explained by the originally good thermal performance of the building types in Cluster II and the poor thermal performance of the building types in Cluster III. Furthermore, it is shown that energy renovation according to the energy target in Case 3 does not result in a higher LCC compared to before renovation in any of the optimizations. In fact, the LCC is decreased by $0.2-2.1 \mathrm{kSEK} / \mathrm{m}^{2}$, or $6-29 \%$. 
Table 11. Specific energy use and LCC in Cases 1-3 for the various clusters.

\begin{tabular}{|c|c|c|c|c|c|c|c|c|c|c|c|c|}
\hline Cluster & \multicolumn{3}{|c|}{$I$} & \multicolumn{3}{|c|}{ II } & \multicolumn{3}{|c|}{ III } & \multicolumn{3}{|c|}{$I V$} \\
\hline Building Type & $1 W$ & $2 W$ & $3 W$ & $4 W$ & $5 W$ & $6 W$ & $1 S$ & $2 S$ & $3 S$ & $4 S$ & $5 S$ & $6 S$ \\
\hline No. of Buildings & 309 & 166 & 25 & 33 & 30 & 18 & 55 & 46 & 16 & 75 & 83 & 64 \\
\hline $\begin{array}{l}\text { Energy use before } \\
\text { renovation-Case } 1\left(\mathrm{kWh} / \mathrm{m}^{2}\right)\end{array}$ & \multicolumn{3}{|c|}{190.7} & \multicolumn{3}{|c|}{117.1} & \multicolumn{3}{|c|}{284.9} & \multicolumn{3}{|c|}{185.8} \\
\hline LCC optimum-Case $2\left(\mathrm{kWh} / \mathrm{m}^{2}\right)$ & \multicolumn{3}{|c|}{$103.7(-46 \%)$} & \multicolumn{3}{|c|}{$89.4(-23 \%)$} & \multicolumn{3}{|c|}{$74.7(-76 \%)$} & \multicolumn{3}{|c|}{$69.3(-64 \%)$} \\
\hline $\begin{array}{l}\text { Swedish building } \\
\text { regulations-Case } 3\left(\mathrm{kWh} / \mathrm{m}^{2}\right)\end{array}$ & \multicolumn{3}{|c|}{$81.7(-57 \%)$} & \multicolumn{3}{|c|}{$77.2(-35 \%)$} & \multicolumn{3}{|c|}{$82.5(-73 \%)$} & \multicolumn{3}{|c|}{$77.3(-59 \%)$} \\
\hline $\begin{array}{l}\text { LCC before renovation-Case } 1 \\
\left(\mathrm{kSEK} / \mathrm{m}^{2}\right)\end{array}$ & \multicolumn{3}{|c|}{5.3} & \multicolumn{3}{|c|}{3.3} & \multicolumn{3}{|c|}{7.2} & \multicolumn{3}{|c|}{4.7} \\
\hline LCC optimum-Case $2\left(\mathrm{kSEK} / \mathrm{m}^{2}\right)$ & \multicolumn{3}{|c|}{$4.0(-24 \%)$} & \multicolumn{3}{|c|}{$2.9(-12 \%)$} & \multicolumn{3}{|c|}{$5.0(-31 \%)$} & \multicolumn{3}{|c|}{$3.4(-28 \%)$} \\
\hline $\begin{array}{l}\text { Swedish building } \\
\text { regulations-Case } 3\left(\mathrm{kSEK} / \mathrm{m}^{2}\right)\end{array}$ & \multicolumn{3}{|c|}{$4.4(-17 \%)$} & \multicolumn{3}{|c|}{$3.1(-6 \%)$} & \multicolumn{3}{|c|}{$5.1(-29 \%)$} & \multicolumn{3}{|c|}{$3.5(-26 \%)$} \\
\hline
\end{tabular}

Annual energy use and total LCC during the optimization period of 50 years for the four building clusters are shown in Figure 8 for Cases 1-3. Cluster $I V$ has the highest energy use and LCC in all three cases, followed by Cluster I, Cluster II and Cluster III. The annual energy use is 4.0-9.5 GWh, 2.4-3.7 GWh, 0.7-3.0 GWh and 5.3-14.8 GWh for Cluster I, Cluster II, Cluster III and Cluster IV, respectively. The corresponding figure for LCC is 200-265 MSEK, 91-104 MSEK, 49-76 MSEK and 260-373 MSEK. When investigating the profitability of the suggested renovation measures between the clusters, there is a clear difference in terms of potential decreases in total LCC. Cluster I and Cluster $I V$ show significant financial gains at the cost-optimum point (Case 2) compared to before energy renovation. The LCC is decreased from 265 MSEK to 200 MSEK in Cluster I and from 373 MSEK to 260 MSEK in Cluster $I V$. It is important to note the corresponding decrease in total energy use from cost-optimal energy renovation of Clusters $I$ and $I V$, which is calculated at $13.8 \mathrm{GWh}$. This is $10.6 \mathrm{GWh}$ more compared to the total decrease in Cluster II and Cluster III (total energy use $=6.7 \mathrm{GWh}$ in Case 1 and 3.5 GWh in Case 2). The consequential effect from the suggested renovation measures with a decreased heating load on the local DH system will be addressed in Section 5.2.4. With regard to the energy targets in Case 3 (Swedish building regulations), the energy use is decreased from $1.3 \mathrm{GWh}$ (Cluster II) to $8.7 \mathrm{GWh}$ (Cluster IV). Following the tendency in terms of decrease in energy use, Cluster IV has the highest LCC savings in Case 3 (101 MSEK). Clusters I-III also show financial gains when performing renovation according to the energy targets in Case 3, varying between 8 and 51 MSEK.
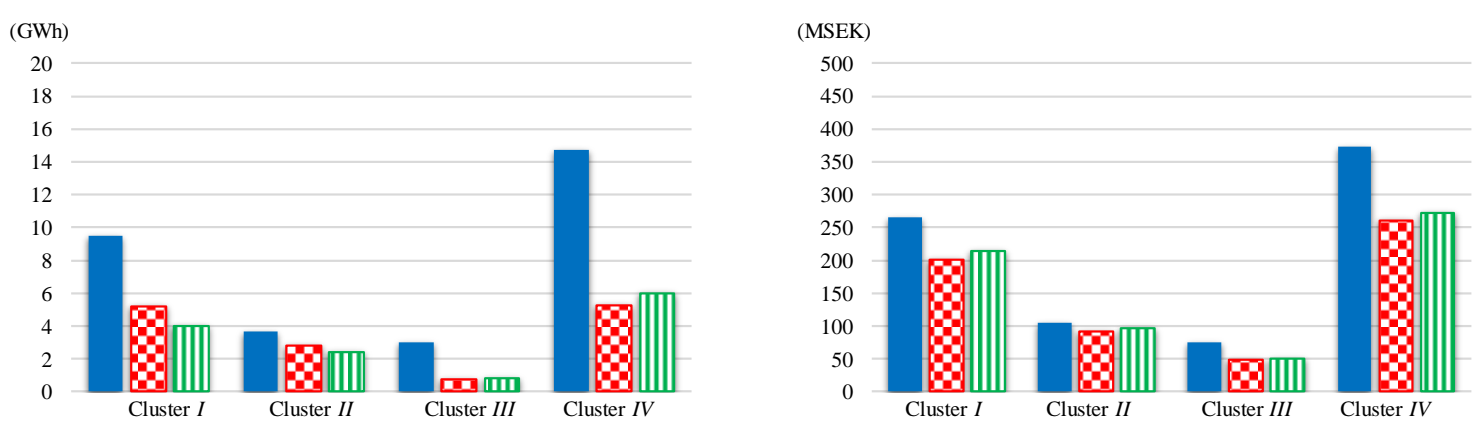

Figure 8. Annual energy use (to the left) and total LCC (to the right) during an optimization period of 50 years for Clusters I-IV in Case 1 (solid blue), Case 2 (red checkered) and Case 3 (green vertical lines).

\subsubsection{District Level}

The following section presents the effects at district level from the cost-optimal renovation of the various building clusters in terms of LCC and energy use. Consequently, the findings can be used as guidance for various stakeholders when investigating the possibilities for energy renovating building 
districts. The total energy use and LCC for the 920 buildings in the studied district, i.e., the four building clusters, are shown in Table 12. Total energy use is decreased in the range between $17.0 \mathrm{GWh}$ and $17.7 \mathrm{GWh}$ compared to before renovation. The highest decrease occurs when performing energy renovation according to the Swedish building regulations (Case 3), where the energy use is decreased by $57 \%$. Interestingly, the percentage difference in energy use in Cases 2, 3 compared to Case 1 varies between $55 \%$ and $57 \%$, showing that the energy use after renovation only varies slightly between Case 2 and Case 3. In terms of expenditure during the 50 years, LCC is calculated at 818 MSEK, 600 MSEK and 632 MSEK for Cases 1-3, respectively. Hence, financial revenue between 186 and 218 MSEK are made possible through renovation according to the cases in this study.

Table 12. Energy use and LCC of the building district in Cases 1-3.

\begin{tabular}{lcc}
\hline \multicolumn{1}{c}{ Case } & $\begin{array}{c}\text { Energy Use } \\
\text { (GWh) }\end{array}$ & LCC (MSEK) \\
\hline Energy use before renovation-Case 1 & 30.9 & 818 \\
LCC optimum-Case 2 & $13.9(-55 \%)$ & $600(-27 \%)$ \\
Swedish building regulations-Case 3 & $13.2(-57 \%)$ & $632(-23 \%)$ \\
\hline
\end{tabular}

The effects of the cost-optimal renovation of each cluster on the district are unique, in terms of both energy use and LCC. This is visualized in Figure 9 for energy renovation of each cluster at the cost-optimum (Case 2), arranged from the cluster with the highest energy savings, Cluster $I V$, to the cluster with the smallest energy savings (Cluster II) compared to before renovation. As shown in Figure 9, the LCC for the district is decreased by 113 MSEK, 64 MSEK, 28 MSEK and 13 MSEK when renovating Cluster IV, Cluster I, Cluster III and Cluster II, respectively. The corresponding annual energy savings are 9.5 GWh, $4.3 \mathrm{GWh}, 2.3 \mathrm{GWh}$ and $0.9 \mathrm{GWh}$. This shows clear differences between the clusters in terms of cost-optimal energy efficiency potential and a potential decrease in LCC. Furthermore, using the proposed approach, it is possible to rank building clusters in a district based on the profitability of suggested energy renovation measures, or energy savings. Hence, various stakeholders can apply and use the approach to obtain the optimal outcome for building energy renovation depending on both financial budget and final objectives.

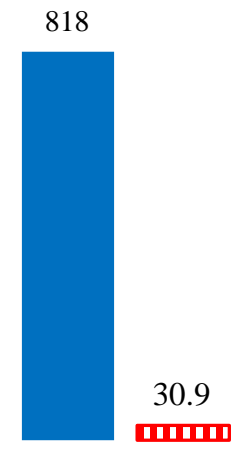

Reference Clusters $I-I V$

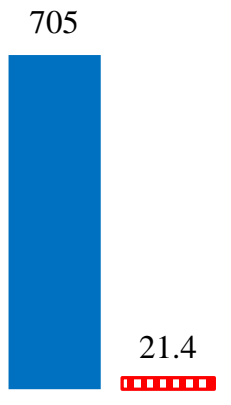

Optimum

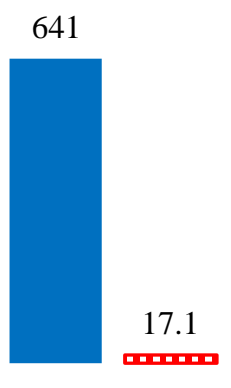

Optimum Clusters $I V+I$
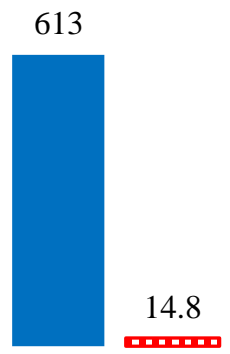

Optimum

Clusters $I V+I+I I I$

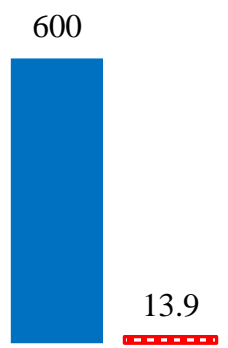

Optimum Clusters $I V+I+I I I+I I$

Figure 9. LCC MSEK (solid blue) and total energy use GWh (red vertical lines) before renovation and when selecting cost-optimal EEMs in the various clusters at LCC optimum (Case 2).

The corresponding effect, i.e., renovation of the various clusters according to the description above for Figure 9, on the DH load for the historic district can be seen in a duration curve in Figure 10 using the time steps in MODEST. The top duration curve shows the duration curve for Case 1, and the second, third, fourth and fifth curves from the top show the duration curve after cost-optimal renovation (Case 2) of Cluster $I V$, Clusters $I V+I$, Clusters $I V+I+I I I$ and Clusters $I V+I+I I I+I I$, respectively. 
Following the tendencies in terms of decreases in energy use and LCC, renovating Cluster $I V$ and Cluster $I$ corresponds to the largest decreases in heat load in the duration curve compared to Case 1 . This can be exemplified by analyzing the peak load for each duration curve. The peak load (9.4 MW) is decreased by $2.6 \mathrm{MW}, 1.3 \mathrm{MW}, 0.6 \mathrm{MW}$ and $0.3 \mathrm{MW}$ when energy renovating Cluster $I V$, Cluster I, Cluster III and Cluster II, respectively.
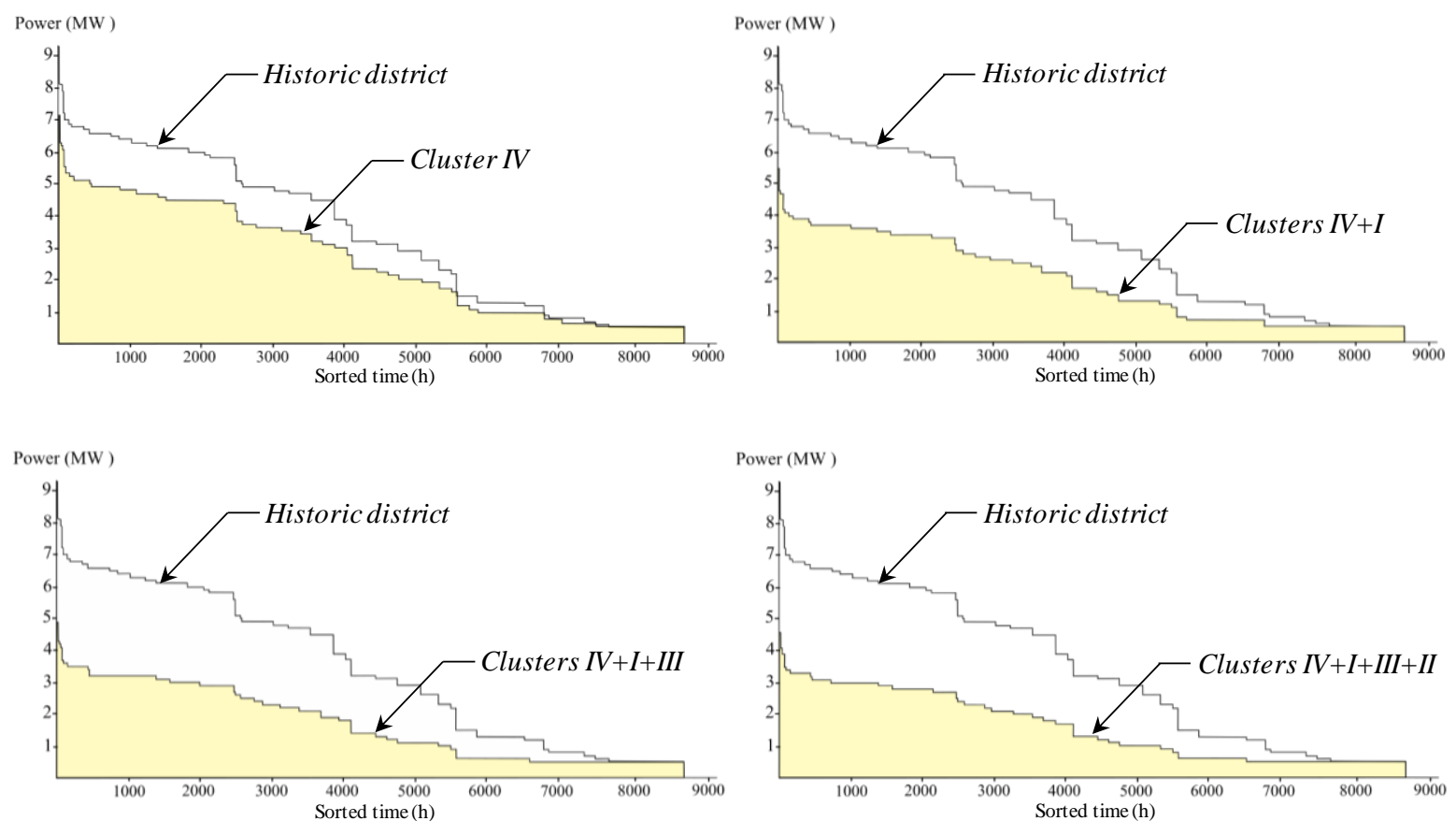

Figure 10. Duration curve when selecting cost-optimal EEMs in the various cluster at LCC optimum (Case 2), as well as before renovation (Case 1) for the historic district. Top left = duration curve for the district in Case 1 and after renovating Cluster $I V$, top right = duration curve after renovating Clusters $I V+I$, bottom left $=$ duration curve after renovating Clusters $I V+I+I I I$ and bottom right $=$ duration curve after renovating Clusters $I V+I+I I I+I I$, respectively.

\subsubsection{City Level}

This section presents the optimization results for the Visby DH system after cost-optimal energy renovation of the building stock. In addition, the effects on the Visby DH system from the cost-optimal renovation of the various building clusters (when arranged by decreased energy use compared to before renovation) have also been investigated and the optimization results are described in this section. In addition, the LCC and environmental impacts from the renovation of a historic district are shown. Table 13 summarizes the results for Cases 1-3. Table 14 summarizes the results when carrying out energy renovation separately for each building cluster at the cost-optimum point (Case 2), ranging from the cluster with the highest energy savings to the cluster with the lowest energy savings, i.e., corresponding to the following order: Cluster $I V$, Clusters $I V+I$, Clusters $I V+I+I I I$ and Clusters $I V+I+I I I+I I$. The results consist of the $\mathrm{DH}$ production, biomass/bio oil supply and electricity used in $\mathrm{DH}$ system, local and global $\mathrm{CO}_{2}$ emissions, system cost and net income for the Visby DH system. 
Table 13. DH production, biomass/bio oil supply and electricity used in the DH system, local and global $\mathrm{CO}_{2}$ emissions, system cost and net income for the Visby $\mathrm{DH}$ system for all cases.

\begin{tabular}{lccc}
\hline DH Production, $\mathbf{C O}_{\mathbf{2}}$ Emissions, System Cost and Net Income & Case 1 & Case 2 & Case 3 \\
\hline DH (GWh/year) & 184.6 & 168.4 & 167.6 \\
Energy supply (GWh/year) & & & \\
$\quad$ Biomass & 149.7 & 143.4 & 143.0 \\
$\quad$ Electricity & 7.2 & 3.6 & 3.4 \\
$\quad$ Bio oil & 0.6 & 0.3 & 0.3 \\
System cost (MSEK/year) & 39.8 & 34.9 & 29.9 \\
System cost over 50 years (MSEK) & 726.7 & 637.3 & 546.0 \\
Net income DH system (MSEK) & 2505 & 2311 & 2388 \\
\hline
\end{tabular}

Table 14. DH production, biomass/bio oil supply and electricity used in the DH system, local and global $\mathrm{CO}_{2}$ emissions, system cost and net income for the Visby $\mathrm{DH}$ system after cost-optimal energy renovation of the various building clusters.

\begin{tabular}{lccccc}
\hline $\begin{array}{l}\text { DH Production, } \mathrm{CO}_{2} \text { Emissions, } \\
\text { System Cost and Net Income }\end{array}$ & Case $\mathbf{1}$ & Cluster IV & Clusters IV + I & $\begin{array}{c}\text { Clusters IV + I } \\
+ \text { III }\end{array}$ & $\begin{array}{c}\text { Clusters IV + I } \\
+I I I+I I\end{array}$ \\
\hline DH (GWh/year) & 184.6 & 175.7 & 171.4 & 169.3 & 168.4 \\
Energy supply (GWh/year) & 149.7 & 146.4 & 144.6 & 144 & 143.4 \\
$\quad$ Biomass & 7.2 & 5.1 & 4.2 & 3.8 & 3.6 \\
$\quad$ Electricity & 0.6 & 0.5 & 0.4 & 0.4 & 0.33 \\
$\quad$ Bio oil & 1667 & 1630 & 1610 & 1600 & 1596 \\
Local CO 2 eq. emissions (ton/year) & 8648 & 6606 & 5718 & 5285 & 5203 \\
Global CO $_{2}$ eq. emissions (ton/year) & 726.7 & 675.5 & 653.6 & 640.8 & 637.3 \\
System cost (MSEK) & 2505 & 2400 & 2347 & 2323 & 2311 \\
Net income DH system (MSEK) & & & & & \\
\hline
\end{tabular}

Cost-optimal energy renovation when targeting LCC optimum (Case 2) and Swedish building regulations (Case 3) affects the performance of the DH system in Visby. As shown in Table 13, biomass heat-only boilers generate the largest part of the DH in all the studied cases. Heat pump and bio oil boilers, as well as landfill gas, supply additional heat during the year in the all studied cases. The largest overall change in terms of environmental performance and system cost of the DH system compared to before energy renovation occurs in Case 3, where DH production by the utilities biomass, bio oil heat-only boilers and heat pumps decrease the most compared with all other cases. The electricity used in the DH system, in this case, is $3.4 \mathrm{GWh} /$ year. The corresponding figures for biomass and bio oil supply are $143.0 \mathrm{GWh}$ and $0.3 \mathrm{GWh}$, respectively. The system cost is reduced the most in Case 3, calculated at 9.9 MSEK/year because of the reduced fuel supply and the use of electricity, as shown in Table 13. The system cost in Case 2 is 34.9 MSEK/year compared to $39.8 \mathrm{MSEK} /$ year before energy renovation. When considering the net income of the DH system, it can be seen that the net income is decreased from 2505 MSEK (Case 1) to between 2311 MSEK (Case 2) and 2388 MSEK (Case 3), due to less DH sold to end-users.

The result of cost-optimal energy renovation when targeting LCC optimum (Case 2) in the various clusters compared with Case 1 shows that selecting cost-optimal EEMs in Clusters $I V+I+I I I+$ II decreases the system cost the most compared to the other alternatives presented in Table 14, i.e., separately energy renovating each cluster ranging from the cluster with the highest energy savings to the cluster with the lowest energy savings. The system cost is decreased by 51.2 MSEK, 73.1 MSEK, 85.9 MSEK and 89.4 MSEK over a period of 50 years when renovating Cluster $I V$, Clusters $I V+I$, Clusters $I V+I+I I I$ and Clusters $I V+I+I I I+I I$, respectively. However, as stated in the section above, a result of renovating the various clusters less DH is sold to end-users, and the revenue is decreased. The net income of the DH system is 2505 MSEK in Case 1, and 2400 MSEK, 2347 MSEK, 2323 MSEK and 2311 MSEK when energy renovating Cluster $I V$, Clusters $I V+I$, Clusters $I V+I+I I I$ and Clusters $I V+I+I I I+I I$, respectively. The local and global $\mathrm{CO}_{2}$ emissions are decreased by 37-71 metric ton and 2042-3445 metric ton, respectively, as presented in Table 14. 
By calculating the revenue for the sold DH and the system cost, as well as LCC and energy use for the various clusters, it is possible to predict the overall outcome of cost-optimal renovation of a historic district in Visby in terms of economics and environmental impact. The LCC for the district and the net income for the DH system over the course of 50 years, as well as annual figures for primary energy use and local and global $\mathrm{CO}_{2}$ emissions, are presented in Figure 11. The net income is 2388 MSEK for the DH system when renovating according to Swedish energy targets (Case 3) compared to the 2311 MSEK at the cost-optimum point (Case 2), which is due to the decrease in electricity use. It is important to mention that the revenue for the DH system is decreased for both Case 2 and Case 3 compared to Case 1 by 194 MSEK and 117 MSEK, respectively. This is because less DH is sold to the end-users. The sold DH to end-users generates an income of 3232 MSEK, 2948 MSEK and 2934 MSEK over a period of 50 years in Case 1, Case 2 and Case 3, respectively. However, there are significant environmental benefits from the suggested renovations. Regarding local and global $\mathrm{CO}_{2}$ emissions, Case 3 corresponds to the lowest emissions of all investigated cases as a result of the largest decrease in used and supplied fuel in the DH system. Local and global $\mathrm{CO}_{2 \text { eq. }}$ emissions are calculated at 1592 metric ton/year (4\% decrease compared to Case 1 ) and 4921 metric ton/year (43\% decrease compared to Case 1), respectively. The primary annual energy use in the city decreases by $5.0 \mathrm{GWh}$ and $5.2 \mathrm{GWh}$ for Case 2 and Case 3, respectively, compared to before renovation ( $57.2 \mathrm{GWh}$ ), which corresponds to a 9\% decrease. A reduction in $\mathrm{CO}_{2}$ emissions, due to decreased heat load is supported by earlier research findings, e.g., $[9,10]$.

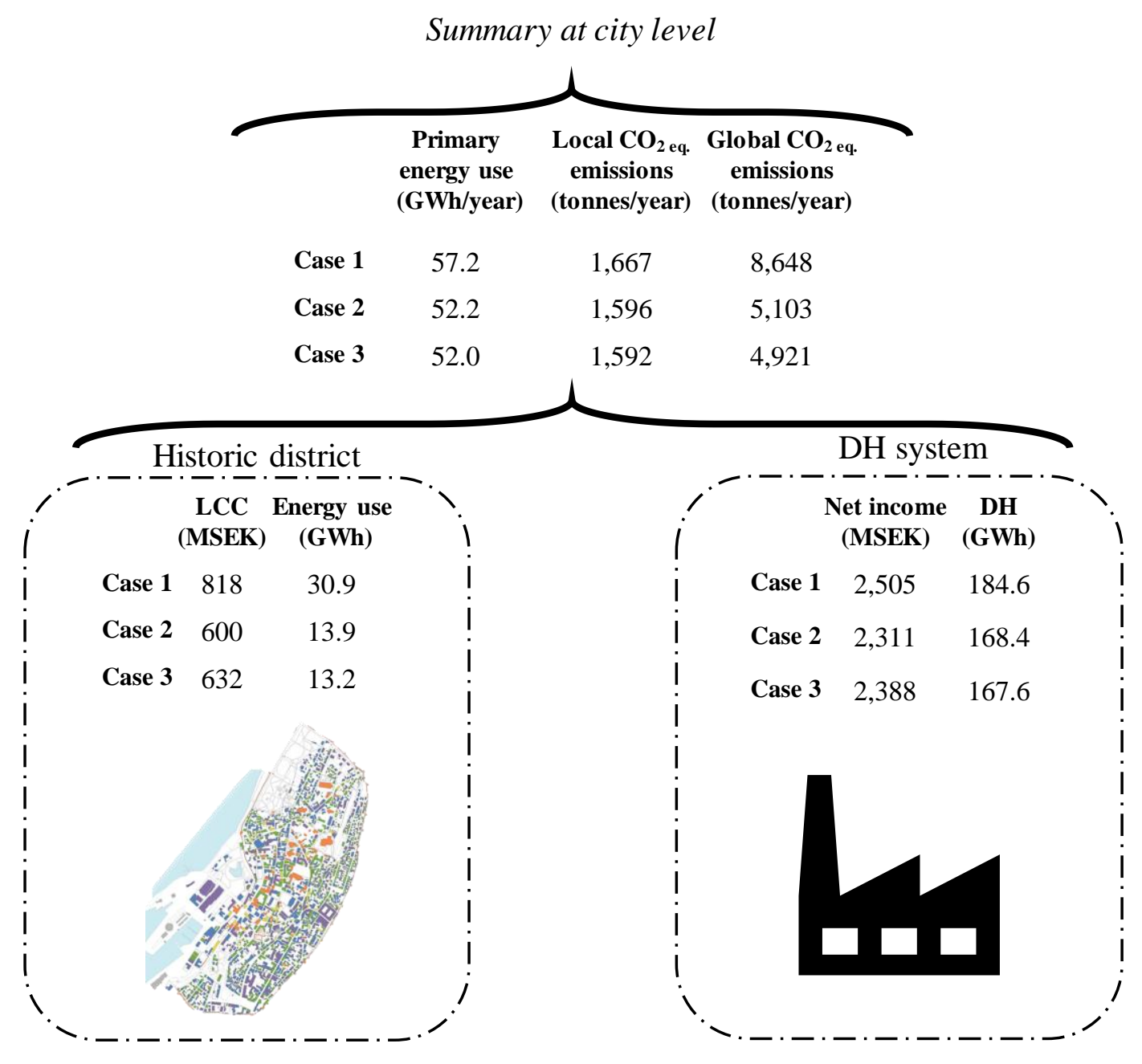

Figure 11. Summary of the LCC for the district and the net income for the DH system over the course of 50 years, as well as annual primary energy use and local and global $\mathrm{CO}_{2}$ emissions. 
There are several interesting aspects to study in future work. When analyzing the effects on the local DH system from the energy renovation of a historic district, it is important to be aware of the time-dependent behavior of the energy systems. This includes larger populations living in cities, resulting in higher resource utilization [44], and expected higher outdoor temperature. A larger population in Visby will most likely increase the heat load of the DH system, due to more buildings being connected to the local energy systems. However, as an effect of global warming, higher outdoor temperatures will occur, resulting in a lower heat load in the DH system. As shown by Shen et al. [45], global climate change also affects the optimal energy renovation strategy for a building and varies depending on location. Other factors that can influence the operation of the DH system include changes in fuel prices, for both the $\mathrm{DH}$ and competing for heating supply systems, as well as technology development and $\mathrm{CO}_{2}$ on fossil fuels [46]. The aforementioned factors are all of interest to study in future work. Concerning the replicability of the results to other cities and energy systems, the authors would like to point out that it is difficult to generalize the effects of cost-optimal energy renovation. This is due to the fact that each building district is unique in terms of dynamic behaviour, and the operation strategy, as well as the fuel mix of the DH system. Hence, the authors recommend performing separate case studies on various local DH systems in cold climate to quantify economic and environmental indicators using the proposed approach. Moreover, another aspect of interest to study is the economic and environmental effects of the expansion to a CHP system. This is especially the case since there is an ongoing process of electrifying the buildings, transport and industry sectors.

\section{Conclusions}

The majority of the research investigations in the field of building LCC optimization have tended to focus on the building owners' perspective. This includes financial gains and improving buildings' environmental performance as a result of cost-optimal energy renovation. However, a connection exists between the energy renovation of DH heated buildings and the performance of the DH system. There is currently a knowledge gap regarding the effects on the local DH system in terms of profitability and environmental performance from cost-optimal energy renovation of a building district. This research proposes a systematic approach to study the effects on $\mathrm{DH}$ system of the above-mentioned parameters from cost-optimal energy renovation of a building district. The study object consists of 920 buildings located in Visby, Sweden, divided into twelve building types and four building clusters. Three different cases are included in the study: Case $1=$ no EEMs on the building envelope corresponding to the reference case, Case $2=$ LCC optimum (the cost-optimum point) and Case $3=$ energy renovation according to Swedish building regulations, BBR.

The results of this study show that by using the proposed approach, it is possible to predict the effects of cost-optimal building renovation concerning economics and environmental performance on the local DH system. In terms of economics, it is revealed that suggested energy renovations in the historic district correspond to financial gains by 186-218 MSEK (23-27\%). However, cost-optimal renovation of the historic district decreases the revenue of the DH system by 117-194 MSEK (5-8\%), due to less $\mathrm{DH}$ sold to end-users. There is, on the other hand, a clear connection between building renovation and decreased local and global $\mathrm{CO}_{2}$ emissions, due to decreased use and supply of fuel, which confirms the findings of previous research within the field. This is especially true when carrying out energy renovation according to BBR, resulting in local and global decreases of 75 metric ton of

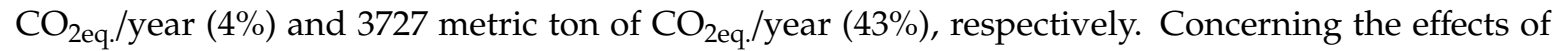
building renovation of the various clusters in the district, it is seen that the total heated area of each cluster is highly significant, as well as the current thermal performance. Cost-optimal renovation with no preset energy target (Case 2) corresponds to a decrease in energy use of $13.8 \mathrm{GWh}(57 \%)$ and financial gains of 178 MSEK (28\%) for Cluster $I$ and Cluster $I V$, where the two clusters are characterized by overall low thermal performance and represent $76 \%$ of the total heated area in the studied district. Meanwhile, the corresponding figures for Cluster II and Cluster III are 3.2 GWh (47\%) and 40 MSEK (22\%). Lastly, the suggested renovation strategies are unique to each building type, due to differences 
in layout and construction. However, the suggested measures for the buildings in each cluster are rather similar because building properties are comparable to a high degree. This can be exemplified through the selection of 24-36 cm floor insulation in Cluster $I$ and Cluster III because of a high $U$-value and the selection of inside insulation of the external walls with $20 \mathrm{~cm}$ in Cluster I and Cluster III at the cost-optimum point, which is also explained by the initially poor thermal performance of the external walls.

Author Contributions: B.M. was the project leader. S.A. was responsible for the optimizations performed in energy system optimization software MODEST and helped with writing the paper connected to the MODEST results. V.M. performed and analyzed the optimization and simulation procedures in OPERA-MILP and IDA ICE, and wrote the paper. B.M. contributed with valuable advice and revision of the manuscript. All authors have read and agreed to the published version of the manuscript.

Funding: This research was funded by of the Swedish Energy Agency, grant number P31669-3 and P44335-1.

Acknowledgments: The authors thank Carolin Boelin and Anna Ekman from GEAB for providing useful data about the DH system in Visby. Furthermore, we would like to thank the Swedish Energy Agency for providing financial support [grant number P31669-3 and P44335-1].

Conflicts of Interest: The authors declare no conflict of interest.

\section{References}

1. U. Persson and S. Werner. Available online: http://www.heatroadmap.eu/resources/STRATEGO\% 20WP2\%20-\%20Background\%20Report\%204\%20-\%20Heat\%20\%26\%20Cold\%20Demands.pdf (accessed on 9 November 2017).

2. The Swedish Energy Agency. Energy in Sweden 2019. An Overview; The Swedish Energy Agency: Stockholm, Sweden, 2019; ISSN 1404-3343.

3. Artola, I.; Rademaekers, K.; Williams, R.; Yearwood, J. Boosting Building Renovation: What potential and value for Europe? 2016, PE 587.326; European Union: Brussels, Belgium, 2016.

4. National Board of Housing, Building and Planning. Energy Use in Buildings-Technical Characteristics and Calculations-Results from the Project BETSI; National Board of Housing, Building and Planning: Karlskrona, Sweden, 2010; ISBN 978-91-86559-83-0.

5. Liu, L.; Rohdin, P.; Moshfegh, B. Investigating cost-optimal refurbishment strategies for the medieval district of Visby in Sweden. Energy Build. 2017, 158, 750-760. [CrossRef]

6. Åberg, M.; Henning, D. Optimisation of a Swedish district heating system with reduced heat demand due to energy efficiency measures in residential buildings. Energy Policy 2011, 39, 7839-7852. [CrossRef]

7. Manfren, M.; Caputo, P.; Costa, G. Paradigm shift in urban energy systems through distributed generation: Methods and models. Appl. Energy 2011, 88, 1032-1048. [CrossRef]

8. Åberg, M.; Widén, J. Development, validation and application of a fixed district heating model structure that requires small amounts of input data. Energy Convers. Manag. 2013, 75, 74-85. [CrossRef]

9. Åberg, M. Investigating the impact of heat demand reductions on Swedish district heating production using a set of typical system models. Appl. Energy 2014, 118, 246-257. [CrossRef]

10. Lundström, L.; Wallin, F. Heat demand profiles of energy conservation measures in buildingsand their impact on a district heating system. Appl. Energy 2016, 161, 290-299. [CrossRef]

11. Le Truong, N.; Dodoo, A.; Gustavsson, L. Effects of heat and electricity saving measures in district-heated multistory residential buildings. Appl. Energy 2014, 118, 57-67. [CrossRef]

12. Lidberg, T.; Gustafsson, M.; Myhren, J.A.; Olofsson, T.; Ödlund, L. Environmental impact of energy refurbishment of buildings within different district heating systems. Appl. Energy 2018, 227, 231-238. [CrossRef]

13. Difs, K.; Bennstam, M.; Trygg, L.; Nordenstam, L. Energy conservation measures in buildings heated by district heating-A local energy system perspective. Energy 2010, 35, 3194-3203. [CrossRef]

14. Lidberg, T.; Oloffson, T.; Trygg, L. System impact of energy efficient building refurbishment within a district heated region. Energy 2016, 106, 45-53. [CrossRef]

15. Division of Energy Systems at Linköping University. Converter; Linköping University: Linköping, Sweden, 2016. 
16. Liu, L.; Rohdin, P.; Moshfegh, B. LCC assessments and environmental impacts on the energy renovation of a multi-family building from the 1890s. Energy Build. 2016, 133, 823-833. [CrossRef]

17. Broström, T.; Eriksson, P.; Liu, L.; Rohdin, P.; Ståhl, F.; Moshfegh, B. A method to assess the potential for and consequences of energy retrofits in Swedish historic buildings. Hist. Environ. Policy Pract. 2014, 5, 150-166. [CrossRef]

18. Gustafsson, S.-I. Mixed integer linear programming and building retrofits. Energy Build. 1998, 28, $191-196$. [CrossRef]

19. Gustafsson, S.-I. Optimal fenestration retrofits by use of MILP programming technique. Energy Build. 2001, 33, 843-851. [CrossRef]

20. Henning, D. Optimisation of Local and National Energy Systems. Development and Use of the MODEST Model. Doctoral Dissertation, No. 559. Division of Energy Systems, Linköping University, Linköping, Sweden, 1999.

21. Gebremedhin, A. A Regional and Industrial Co-Operation in District Heating Systems. Doctoral Dissertation, No. 849. Division of Energy Systems, Linköping University, Linköping, Sweden, 2003.

22. Sundberg, G.; Henning, D. Investments in combined heat and power plants: Influence of fuel price on cost minimised operation. Energy Convers. Manag. 2002, 43, 639-650. [CrossRef]

23. Sjödin, J.; Henning, D. Calculating the marginal costs of a district-heating utility. Appl. Energy 2004, 78, 1-18. [CrossRef]

24. Henning, D.; Amiri, S.; Holmgren, K. Modelling and optimization of electricity, steam and district heating production for a local Swedish utility. Eur. J. Oper. Res. 2006, 175, 1224-1247. [CrossRef]

25. Rolfsman, B. $\mathrm{CO}_{2}$ emission consequences of energy measures in buildings. Build. Environ. 2002, 37, 1421-1430. [CrossRef]

26. Åberg, M.; Widén, J.; Henning, D. Sensitivity of district heating system operation to heat demand reductions and electricity price variations: A Swedish example. Energy 2012, 41, 525-540. [CrossRef]

27. Weinberger, G.; Amiri, S.; Moshfegh, B. On the benefit of integration of a district heating system with industrial excess heat: An economic and environmental analysis. Appl. Energy 2017, 191, 454-468. [CrossRef]

28. Amiri, S.; Henning, D.; Karlsson, B.G. Simulation and introduction of a CHP plant in a Swedish biogas system. Renew. Energy 2013, 49, 242-249. [CrossRef]

29. Amiri, S.; Weinberger, G. Increased cogeneration of renewable electricity through energy cooperation in a Swedish district heating system-A case study. Renew. Energy 2018, 116, 866-877. [CrossRef]

30. Berg, F. Categorising a Historic Building Stock-An Interdisciplinary Approach; UU-259149; Uppsala University: Uppsala, Sweden, 2015.

31. Broström, T.; Donarelli, A.; Berg, F. For the categorisation of historic buildings to determine energy saving. Agathon Int. J. Archit. Art Des. 2017, 1, 135-142.

32. Public Health Agency of Sweden. Common Advice about Indoor Tempeatures; FoHMFS 2014:17; Public Health Agency of Sweden: Stockholm, Sweden, 2014.

33. Wikells. Section Facts 17/18-Techno-economic compilation.

34. Adalberth, K.; Wahlström, Å. Energy Audit of Buildings-Apartment Buildings and Facilities; Swedish Standards Institute: Stockholm, Sweden, 2009; ISBN 978-91-7162-755-1.

35. European Central Bank. Euro Exchange Rates. Available online: https://www.ecb.europa.eu/stats/exchange/ eurofxref/html/eurofxref-graph-sek.en.html (accessed on 3 September 2018).

36. Swedish Energy Agency and National Board of Housing, Building and Planning. Proposals for National Stragegy for Energy Efficiency Renovation of Building; Swedish Energy Agency and National Board of Housing, Building and Planning: Karlskrona, Sweden, 2013; ISBN 978-91-7563-049-6.

37. Mälarenergi. Buy a New Heat Exchanger. Available online: https://www.malarenergi.se/fjarrvarme/forhusagare/kop-ny-fjarrvarmecentral (accessed on 27 November 2018).

38. ASHRAE. ASHRAE IWEC2 Weather Files for International Locations. Available online: http://ashrae. whiteboxtechnologies.com/ (accessed on 2 March 2017).

39. Swedenergy. Environmental Assessment of District Heating. Available online: https://www.energiforetagen. se/statistik/fjarrvarmestatistik/miljovardering-av-fjarrvarme/miljovarden-fran-tidigare-ar/ (accessed on 27 November 2018).

40. Grönkvist, S.; Sjödin, J.; Westermark, M. Models for assessing net $\mathrm{CO}_{2}$ emissions applied on on district heating technologies. Int. J. Energy Res. 2003, 27, 601-613. [CrossRef] 
41. Swedenergy. Agreement in the Heating Market Committe 2018; Swedenergy: Stockholm, Sweden, 2018.

42. The Swedish Energy Agency. Energy Statistics. Available online: http://www.energimyndigheten.se/statistik/ den-officiella-statistiken/alla-statistikprodukter/ (accessed on 20 February 2019).

43. Milić, V.; Ekelöw, K.; Moshfegh, B. On the performance of LCC optimization software OPERA-MILP by comparison with building energy simulation software IDA ICE. Build. Environ. 2018, 128, 305-319. [CrossRef]

44. Vassileva, I.; Campillo, J.; Schwede, S. Technology assessment of the two most relevant aspects for improving urban energy efficiency identified in six mid-sized European cities from case studies in Sweden. Appl. Energy 2017, 194, 808-818. [CrossRef]

45. Shen, P.; Braham, W.; Yi, Y. The feasibility and importance of considering climate change impacts in building retrofit analysis. Appl. Energy 2019, 233, 254-270. [CrossRef]

46. Le Truong, N.; Gustafsson, L. Minimum-cost district heat production systems of different sizes under different environmental and social cost scenarios. Appl. Energy 2014, 136, 881-893. [CrossRef]

(C) 2020 by the authors. Licensee MDPI, Basel, Switzerland. This article is an open access article distributed under the terms and conditions of the Creative Commons Attribution (CC BY) license (http://creativecommons.org/licenses/by/4.0/). 